\title{
The Fox and the Rabbits_-Environmental Variables and Population Genetics (1) Replication Problems in Association Studies and the Untapped Power of GWAS (2) Vitamin A Deficiency, Herpes Simplex Reactivation and Other Causes of Alzheimer's Disease
}

\author{
C. J. Carter \\ PolygenicPathways, Flat 4, 20 Upper Maze Hill, St Leonards-on-Sea, East Sussex, TN38 OLG, UK \\ Correspondence should be addressed to C. J. Carter, chris_car@yahoo.com
}

Received 13 March 2011; Accepted 20 April 2011

Academic Editor: A. Conti

Copyright ( 92011 C. J. Carter. This is an open access article distributed under the Creative Commons Attribution License, which permits unrestricted use, distribution, and reproduction in any medium, provided the original work is properly cited.

\begin{abstract}
Classical population genetics shows that varying permutations of genes and risk factors permit or disallow the effects of causative agents, depending on circumstance. For example, genes and environment determine whether a fox kills black or white rabbits on snow or black ash covered islands. Risk promoting effects are different on each island, but obscured by meta-analysis or GWAS data from both islands, unless partitioned by different contributory factors. In Alzheimer's disease, the foxes appear to be herpes, borrelia or chlamydial infection, hypercholesterolemia, hyperhomocysteinaemia, diabetes, cerebral hypoperfusion, oestrogen depletion, or vitamin A deficiency, all of which promote beta-amyloid deposition in animal models—without the aid of gene variants. All relate to risk factors and subsets of susceptibility genes, which condition their effects. All are less prevalent in convents, where nuns appear less susceptible to the ravages of ageing. Antagonism of the antimicrobial properties of betaamyloid by Abeta autoantibodies in the ageing population, likely generated by antibodies raised to beta-amyloid/pathogen protein homologues, may play a role in this scenario. These agents are treatable by diet and drugs, vitamin supplementation, pathogen detection and elimination, and autoantibody removal, although again, the beneficial effects of individual treatments may be tempered by genes and environment.
\end{abstract}

\section{Introduction}

If there is one factor common to complex polygenic diseases it is the heterogeneity in both gene and risk factor association studies.

Although these have discovered key genes and risk factors, the results for most are invariably confounded by conflicting data [1]. In the genetic arena, the clear familial component of many diseases has driven the search for major genes using genome-wide association studies (GWAS) with large numbers of patients pooled from different regions [2]. Such studies have been able to discover rare variants that play a major role in a small percentage of patients, for example VIPR2 in schizophrenia [3]. However, in complex diseases, these have failed to find major genes relevant to all patients [4], instead unearthing yet more genes of small effect, whose risk promoting effects are yet again contested, as is the case with CR1 and PICALM, which have not been confirmed as risk factors for Alzheimer's disease in Chinese patients [5] despite extensive evidence in Caucasian studies [6]. GWAS studies have, however, been more successful in uncovering larger numbers of genes of greater effect for simpler traits such as lipid levels [7].

Viruses and other pathogens have been implicated as risk factors in many diseases, although again, conflicting evidence leads to scepticism in many areas. For example, the involvement of the Epstein-Barr virus in multiple sclerosis is hotly contested [8-10]. 
Gene-gene and gene-environment interactions may play an important role in such inconsistency. For example, the risk promoting effects of genes can be better explained when using pathway analysis or combining the effects of genes with common function, rather than by studying single genes in isolation $[11,12]$. Genes and risk factors can also act together, and in certain cases genes can be linked to environmental variables. For example, many of the genes implicated in schizophrenia or Alzheimer's disease are involved in the life cycles of the pathogens involved in the diseases $[13,14]$. Environment-environment interactions are also apparent. For example, the effects of vitamin $\mathrm{E}$ on lifespan, or on resistance to various infections can be null, deleterious, or protective, depending on confounding factors such as age, exercise, smoking, and vitamin C consumption [15-17].

Complex diseases are also composed of many endophenotypes or underlying pathologies, and different genes or risk factors may contribute to any of these. Many different processes contribute to cell death in Alzheimer's disease, for example, beta amyloid, glutamate, calcium, or free radical mediated toxicity $[18,19]$. The efficiency of each of these subprocesses is controlled by genes, many of which have been implicated in association studies (see Table 1).

In genetic association studies, the drive has been to increase statistical power by increasing the numbers of subjects enrolled. This has resulted in the discovery of important genes and rare genetic variants, but has not delivered genes that confer a high degree of risk in the majority of patients. However, as illustrated below, more could perhaps be gained by a reanalysis of existing data in relation to other genetic and risk factor variables that could result in elucidation of the causes rather than the risks.

\section{Methods}

Alzheimer's disease susceptibility genes and risk factors are stocked in an online database at http://www.polygenicpathways.co.uk/alzenvrisk.htm. KEGG pathway analysis of over 400 associated genes was performed [20], and the results of the exercise were posted at http://www.polygenicpathways.co.uk/alzkegg.htm. In these figures, yellow genes have been implicated in Alzheimer's disease and red genes are also implicated in the herpes simplex life cycle. Other gene-risk factor relationships were identified by literature survey. B cell and $\mathrm{T}$ cell epitopes within the beta-amyloid peptide were identified using the immune epitope database server http:// tools.immuneepitope.org/main/index.html which predicts the antigenicity of peptide sequences, based on their charge and hydrophobicity properties [21]. Sequence comparisons of the beta-amyloid peptide versus selected bacterial, fungal, or viral proteomes was performed using the NCBI blast server $[22,23]$.

\section{Results and Discussion}

3.1. Kegg Pathway Analysis of Alzheimer's Disease Susceptibility Genes. The overall results of this analysis are shown in Table 1 . The pathways include many that are relevant to the known pathologies and risk factors of Alzheimer's disease, including the Alzheimer's disease pathway itself, primarily related to beta-amyloid and tau processing, but also to glutamate-related pathways (long-term potentiation and depression), apoptosis, insulin and diabetes pathways, neurotrophin signalling, oxidative stress (glutathione/oxidative phosphorylation), cerebral hypometabolism (oxidative phosphorylation, glycolysis and the Krebs cycle), arginine and proline metabolism (including nitric oxide), and folate, methionine and homocysteine metabolism, and steroid hormone synthesis (together with androgen and oestrogen receptors AR, ESR1, and ESR2). PPAR signalling regulates many lipoprotein-related genes and cholesterol/lipid pathways are dispersed in terpenoid backbone biosynthesis (FDPS, HMGCR, HMGCS2), steroid hormone biosynthesis (HSD11B1), steroid biosynthesis (DHCR24, LIPA, SOAT1), glycerolipid metabolism (ALDH2, LIPC, LPL), and bile acid biosynthesis $(\mathrm{CH} 25 \mathrm{H}, \mathrm{CYP} 46 \mathrm{~A} 1)$ pathways. Immune, complement, and cytokine-related pathways figure prominently, as do several pathogen defence pathways including the DNA sensing retinoic acid inducible gene (RIG-1) pathways that react to viral DNA/RNA by increasing the expression of interferons and other antiviral genes, and the Toll receptor and NOD pattern recognition pathway that control immune and cytokine networks [24-26]. Glutathione pathways were also present. Glutathione has potent viricidal and bactericidal properties and is often depleted by infections [27-30]. A number of pathogen entry pathways are also concerned, and although C. Pneumoniae or C. Neoformans pathways are not specifically represented, many of these pathways can be considered as generic pathways relevant to many bacteria and other pathogens. The H. Pylori pathway contains only two genes, IL8 and CSK, but others can be added to this list including all members of the PI 3-kinase/AKT signalling network which is activated by the $H$. pylori protein CagA [31] or Toll receptor pathways that are activated by H. Pylori heat shock protein, HSP60 [32]. Similarly, there is no specific HSV-1 viral entry pathway in the KEGG database, but the virus uses actin pathways, endocytosis, protein processing, and DNA repair pathways during its life cycle, which are heavily represented [33].

3.2. Vitamin-A-Related Genes. These were identified by literature survey and the most directly relevant are shown in Table 2. Of particular interest is a close relationship between cholesterol/lipoprotein-related genes and vitamin A. Both retinols and cholesterol are transported by lipoproteins, and the clusterin receptor, LRP2/megalin, is a key retinol entry point. APOE4 is the isoform least able to bind to retinyl palmitate. ABCA1 is also involved in cholesterol and retinol transport. Several genes (ALDH2, CYP46A1, GSTM1, GSTP1, LIPA, LPL, and LRAT) are involved in Vitamin A metabolism, and 24-s hydroxycholesterol, the product of CYP46A1, is a ligand for retinoic acid receptors (RARA and RARG). Retinoid coreceptors and binding partners include RXRA, ESR1, KLF5 NPAS2, NR1H2, PARP1, PIN1, POU2F1, PPARA, PPARG, THRA, UBQLN1, and VDR. Retinoids modulate APP processing, via regulation of beta and gamma secretases while the RIG-1 pathway is crucial in viral defence. 
A large number of genes are also regulated by retinoids or retinoid receptors.

\subsection{The Fox, the Rabbits, Gene, and Environmental Variables.} This is an adaptation of Lees's classical population genetics example of the peppered moth, whose dark or pale colouring confers advantage or disadvantage depending upon the degree of industrial pollution that covers trees with soot. It has served to illustrate the concept of natural selection where, over time, dark genes become more common in polluted areas, an effect that could eventually lead to speciation [34].

On two islands one covered in snow and the other in black volcanic ash live an equal number of black and white rabbits and a family of foxes, who will find it easier to trap the black rabbits on the snowy island and the white rabbits on the island covered in black ash. Gene association studies would correctly identify the black and white genes as being protective or risk promoting depending upon the environment. The snow, the ash, or the fox, being equally present on each island, regardless of the toll of dead rabbits, could not be considered as risk factors. Genetic meta-analysis or pooled GWAS data would also rule out any genetic involvement, leaving no susceptibility genes, no risk factors, and no cause. However, a GWAS study, apportioning the genetic data in relation to ash, snow, and fox would be able to correctly surmise that the white gene is a risk factor on the ash-covered island, and the black gene a risk factor on the snowy island, as would have D. R. Lees. Again the fox is undetectable, being present in all compartments.

On other similar islands, live further populations of black and white rabbits with no fox, an equal number of deaths due to old age, and no reason to investigate either genes or risk factors. However, it is only by including this island, again partitioning GWAS data in relation to all variables, that the genes, the risk factors, and the cause can be correctly allotted their respective roles.

In this example, the genes and environmental variable are risk or protective factors for the cause as well as for the deaths, depending on circumstance. The genes or risk factors are not killing the rabbits, but are allowing the cause to do so. Nonstratified association studies would thus seem to be ill-suited to find important genes, risk factors, or causes, and the pursuit of greater statistical power may well be futile, although such strategies can find rare variants that may cause disease in a minority of patients, which is evidently useful. However, for the majority of cases, much could perhaps be gained from a reappraisal of existing data and by partitioning GWAS data in relation to the many known risk factors in each disease.

The situation is evidently more complex in polygenic diseases, where hundreds of interacting genes, many risk factors, and probably many causes are present. This is already appreciated, and several groups have analysed the statistical problems involved due to the mass of genes and risk factors [35-37]. However, it is likely that an appropriate selection of genes and risk factors could markedly affect the degree of risk. For example, the odds ratio for APOE4 was shown to be 1.67 in Alzheimer's disease patients without cerebral HSV-1 DNA and 16.8 in patients where viral DNA was detected [38].
The population genetics example, and the discussion below, suggests that certain susceptibility genes are restricted to risk factor subsets.

From the above, it would appear that a cause can be present in equal proportion in control and disease populations but should be able to produce the pathological features of the disease, and the disease incidence should be reduced where the causes are few. A cause can kill regardless of the genes (black or white) or risk factors (snow or volcanic ash) but its effects are tempered by a combination of the two $($ fox + snow + black gene or fox + ash + white gene $=$ death and fox + snow + white gene or fox + ash + black gene, or no fox and any combination $=$ life). The genes and risk factors are, however, both able to influence the cause.

In relation to Alzheimer's disease, beta-amyloid deposition can be produced by herpes simplex [189-191] or chlamydia pneumoniae infection [192, 193], hypercholesterolemia (which also causes cholinergic neuronal loss and memory deficits in rats [194-197]), by or hyperhomocysteinaemia, an effect reversed by folate and vitamin-B12 [198], by NGF deprivation [199], by reduced cerebral perfusion (hypoxia, cerebral ischaemia, or carotid artery occlusion [200-203]), as well as by experimental diabetes and streptozotocin [204, 205], oestrogen depletion [206], or vitamin A deficiency, which also reduces choline acetyltransferase activity in the forebrain [207] —all without the aid of any variant genes, in animal models. While none of the animal models faithfully reproduce the entire symptomatology of Alzheimer's disease, in the clinical setting these risk factors coexist to varying degrees, rendering the situation rather more complex.

The risk factors in Alzheimer's disease include herpes simplex infection [208] acting in combination with APOE4 [209], C. Pneumoniae [210, 211] or Helicobacter pylori infection [212, 213], mild hypercholesterolaemia [214], but declining cholesterol levels from midlife to late life [215], atherosclerosis of the carotid arteries, leptomeningeal arteries, or the circle of Willis, and stroke, leading to cerebral hypoperfusion [216-219], hyperhomocysteinaemia [220], type 2 diabetes and modified insulin metabolism [221], agerelated loss of sex steroid hormones in both women and men [222], but high total oestradiol levels [223, 224], and vitamin A deficiency [225]. These factors may be confounded by interrelationships, and in some cases by the fact that death due to other causes-for example, atherosclerosis-related myocardial infarction or stroke may lead to an apparent paucity of comorbid risk factors in Alzheimer's disease groups at later ages.

The genes implicated in Alzheimer's disease are related to the herpes simplex life cycle $[13,226]$, bacterial and viral entry pathways, viral and pathogen defence (Table 1), and the immune network [227], cholesterol and lipoprotein pathways [11, 228], folate and homocysteine pathways [229], and insulin, or neurotrophin signalling pathways, steroid metabolism and receptors (Table 1 and 2), and vitamin A metabolism and function (Table 2).

The genes, risk factors and agents known to increase beta-amyloid deposition all concur, suggesting that Alzheimer's disease is multifactorial with many foxes, each with 
TABLE 1: A summary of the KEGG pathway analysis of Alzheimer's disease susceptibility genes. The number of genes in each pathway is shown in brackets (see http://www.polygenicpathways.co.uk/alzkegg.htm for coloured figures).

\begin{tabular}{|c|c|c|}
\hline Immune system and pathogen defence & Pathogen entry pathways & $\begin{array}{l}\text { Structural and DNA repair } \\
\text { (and HSV-1 pathways) }\end{array}$ \\
\hline $\begin{array}{l}\text { Cytokine-cytokine receptor interaction } \\
\text { (13) }\end{array}$ & Chagas disease (17) & Regulation of actin cytoskeleton (8) \\
\hline Hematopoietic cell lineage (11) & Hepatitis C (13) & Endocytosis (8) \\
\hline $\begin{array}{l}\text { Complement and coagulation cascades } \\
\text { (11) }\end{array}$ & Malaria (12) & $\begin{array}{l}\text { Protein processing in endoplasmic } \\
\text { reticulum }(8)\end{array}$ \\
\hline $\begin{array}{l}\text { Natural killer cell-mediated cytotoxicity } \\
\text { (10) }\end{array}$ & Amoebiasis (11) & Nucleotide excision repair (4) \\
\hline Chemokine signaling pathway (9) & $\begin{array}{l}\text { Microbial metabolism in diverse } \\
\text { environments (10) }\end{array}$ & Spliceosome (4) \\
\hline Phagosome (9) & Leishmaniasis (9) & DNA replication (3) \\
\hline Lysosome (8) & Viral myocarditis (6) & Homologous recombination (3) \\
\hline T cell receptor signaling pathway (8) & Staphylococcus aureus infection (6) & RNA transport (2) \\
\hline Toll-like receptor signaling pathway (8) & Bacterial invasion of epithelial cells (4) & Mismatch repair (2) \\
\hline $\begin{array}{l}\text { NOD-like receptor signaling } \\
\text { pathway-(7) }\end{array}$ & Pathogenic Escherichia coli infection (3) & Base excision repair (2) \\
\hline Systemic lupus erythematosus (7) & $\begin{array}{l}\text { Epithelial cell signaling in Helicobacter } \\
\text { pylori infection (2) }\end{array}$ & Apoptosis and oxidative stress \\
\hline B cell receptor signaling pathway (6) & Shigellosis (2) & Apoptosis (10) \\
\hline Graft-versus-host disease (6) & Metabolism & Drug metabolism cytochrome P450 (6) \\
\hline Cytosolic DNA-sensing pathway (5) & Oxidative phosphorylation (14) & Glutathione metabolism (5) \\
\hline Antigen processing and presentation (5) & Arginine and proline metabolism (7) & $\begin{array}{l}\text { Metabolism of xenobiotics by } \\
\text { cytochrome P450 (5) }\end{array}$ \\
\hline $\begin{array}{l}\text { Intestinal immune network for IgA } \\
\text { production (5) }\end{array}$ & Glycolysis/gluconeogenesis (5) & Peroxisome (3) \\
\hline Type I diabetes mellitus (5) & $\begin{array}{l}\text { Valine, leucine, and isoleucine } \\
\text { degradation (4) }\end{array}$ & Drug metabolism—other enzymes (2) \\
\hline Salivary secretion (5) & One carbon pool by folate (3) & Signalling pathways \\
\hline Adipocytokine signaling pathway (5) & Terpenoid backbone biosynthesis (3) & MAPK signalling (35) \\
\hline Fc epsilon RI signaling pathway (4) & Pyruvate metabolism (3) & Calcium signaling pathway (13) \\
\hline Allograft rejection (4) & Citrate cycle (TCA cycle) (3) & PPAR signaling pathway (12) \\
\hline TGF-beta signaling pathway (4) & $\begin{array}{l}\text { Glycine, serine, and threonine } \\
\text { metabolism (3) }\end{array}$ & Neurotrophin signaling pathway (12) \\
\hline Autoimmune thyroid disease (4) & Protein digestion and absorption (3) & Wnt signaling pathway (10) \\
\hline RIG-I-like receptor signaling pathway (4) & Tyrosine metabolism (3) & Insulin signaling pathway (9) \\
\hline Jak-STAT signaling pathway (4) & Steroid hormone biosynthesis (3) & VEGF signaling pathway (7) \\
\hline Fc gamma R-mediated phagocytosis (3) & Steroid biosynthesis (3) & Vascular smooth muscle contraction (6) \\
\hline Leukocyte transendothelial migration (3) & Glycerolipid metabolism (3) & Notch signaling pathway (5) \\
\hline Asthma (3) & $\begin{array}{l}\text { Porphyrin and chlorophyll metabolism } \\
\text { (3) }\end{array}$ & $\mathrm{ABC}$ transporters $(5)$ \\
\hline \multirow[t]{8}{*}{ Primary immunodeficiency (2) } & Histidine metabolism (2) & Renin-angiotensin system (4) \\
\hline & Sphingolipid metabolism (2) & Cardiac muscle contraction (4) \\
\hline & Cysteine and methionine metabolism (2) & mTOR signaling pathway (3) \\
\hline & Purine metabolism (2) & ErbB signaling pathway (3) \\
\hline & Tryptophan metabolism (2) & $\begin{array}{l}\text { Aldosterone-regulated sodium } \\
\text { reabsorption ( } 3 \text { ) }\end{array}$ \\
\hline & Lysine degradation (2) & $\begin{array}{l}\text { Progesterone-mediated oocyte } \\
\text { maturation ( } 3 \text { ) }\end{array}$ \\
\hline & Primary bile acid biosynthesis (2) & GnRH signaling pathway (2) \\
\hline & & Hedgehog signaling pathway (2) \\
\hline
\end{tabular}


TABLE 2: The relationships of Alzheimer's disease susceptibility genes with vitamin A. NF = none found.

\begin{tabular}{|c|c|c|}
\hline Gene & Name & Relationships with vitamin A \\
\hline \multicolumn{3}{|c|}{ Transport and entry } \\
\hline ALB & Albumin & $\begin{array}{l}\text { Together with retinol binding protein forms the retinol } \\
\text { transporter [39] }\end{array}$ \\
\hline APOE & Apolipoprotein E & $\begin{array}{l}\text { Expression regulated by LXR/RXR dimers [40] } \\
\text { Involved in retinyl palmitate transport }[41]\end{array}$ \\
\hline TTR & $\begin{array}{l}\text { Transthyretin (prealbumin, } \\
\text { amyloidosis type I) }\end{array}$ & Carrier protein for the retinol binding protein [42] \\
\hline APOA1 & Apolipoprotein A-I & $\begin{array}{l}\text { RORA target [43]: associates with transthyretin in } \\
\text { plasma [44] }\end{array}$ \\
\hline HSPG2 & $\begin{array}{l}\text { Perlecan: (heparan sulfate } \\
\text { proteoglycan } 2 \text { ) }\end{array}$ & Binds to transthyretin [45] \\
\hline $\mathrm{A} 2 \mathrm{M}$ & Alpha-2-macroglobulin & Synthesis decreased in vitamin-A- deficient rats [46] \\
\hline ABCA1 & $\begin{array}{l}\text { ATP-binding cassette, } \\
\text { subfamily A (ABC1), } \\
\text { member } 1\end{array}$ & $\begin{array}{l}\text { 22R-hydroxycholesterol and 9-cis-retinoic acid induce } \\
\mathrm{ABCA} 1 \text { expression and cholesterol efflux in brain cells } \\
\text { and decrease Beta-amyloid secretion [47]. Involved in } \\
\text { retinol and alpha- and gamma-tocopherol transport } \\
{[48,49]}\end{array}$ \\
\hline CLU & $\begin{array}{l}\text { Clusterin (APOJ) LRP2 } \\
\text { ligand }\end{array}$ & $\begin{array}{l}\text { The clusterin promoter contains a RARE sequence: } \\
\text { Expression is suppressed by all-trans-retinoic acid [50]. } \\
\text { Vitamin A deficiency increases clusterin expression in } \\
\text { sertoli cells [51] }\end{array}$ \\
\hline LRP2 & $\begin{array}{l}\text { Low density } \\
\text { lipoprotein-related protein } \\
2 \text { (clusterin receptor) }\end{array}$ & $\begin{array}{l}\text { Mediates the endocytosis of retinol via binding to } \\
\text { retinol binding proteins and transthyretin }[52,53]\end{array}$ \\
\hline LRPAP1 & $\begin{array}{l}\text { Low density lipoprotein } \\
\text { receptor-related protein } \\
\text { associated protein } 1\end{array}$ & Regulates the uptake of retinol by LRP2 [54] \\
\hline \multicolumn{3}{|c|}{ Metabolism } \\
\hline ALDH2 & $\begin{array}{l}\text { Aldehyde dehydrogenase } 2 \\
\text { family (mitochondrial) }\end{array}$ & $\begin{array}{l}\text { Exhibits low NAD }(+) \text {-dependent retinaldehyde activity } \\
{[55] \text { : regulated by RARB [56] }}\end{array}$ \\
\hline CYP46A1 & $\begin{array}{l}\text { Cytochrome P450, family } \\
46 \text {, subfamily A, } \\
\text { polypeptide } 1\end{array}$ & $\begin{array}{l}\text { Synthesises } 24-S \text { hydroxycholesterol, a ligand for RARA } \\
\text { and RARG [57] }\end{array}$ \\
\hline GSTM1 & $\begin{array}{l}\text { Glutathione S-transferase } \\
\text { M1 }\end{array}$ & $\begin{array}{l}\text { Weakly catalyses the enzymic isomerization of } \\
13 \text {-cis-retinoic acid to all-trans-retinoic acid [58] }\end{array}$ \\
\hline GSTP1 & $\begin{array}{l}\text { Glutathione S-transferase } \\
\text { pi }\end{array}$ & $\begin{array}{l}\text { Catalyses the enzymic isomerization of } 13 \text {-cis-retinoic } \\
\text { acid to all-trans-retinoic acid [58] }\end{array}$ \\
\hline LIPA & $\begin{array}{l}\text { Lipase A, lysosomal acid, } \\
\text { cholesterol esterase } \\
\text { (Wolman disease) }\end{array}$ & $\begin{array}{l}\text { Metabolises carotenoid mono- and diesters providing a } \\
\text { source of free carotenoids in the gut [59] }\end{array}$ \\
\hline LPL & Lipoprotein lipase & Metabolises retinyl esters [60]. RORA target [61] \\
\hline LRAT & $\begin{array}{l}\text { Lecithin retinol } \\
\text { acyltransferase } \\
\text { (phosphatidylcholine- } \\
\text { retinol } \\
\text { O-acyltransferase) }\end{array}$ & $\begin{array}{l}\text { Lecithin retinol acyltransferase } \\
\text { (phosphatidylcholine-retinol O-acyltransferase) }\end{array}$ \\
\hline MEF2A & $\begin{array}{l}\text { Myocyte enhancer factor } \\
2 \mathrm{~A}\end{array}$ & $\begin{array}{l}\text { Regulates beta-carotene } 15,15^{\prime} \text {-monooxygenase } 1 \\
\text { which cleaves beta-carotene to all-trans retinal and is } \\
\text { the key enzyme in the intestinal metabolism of } \\
\text { carotenes to vitamin A [62] }\end{array}$ \\
\hline \multicolumn{3}{|c|}{ Receptors, coreceptors and receptor binding partners } \\
\hline CHD4 & $\begin{array}{l}\text { Chromodomain helicase } \\
\text { DNA binding protein } 4\end{array}$ & Binds to RORG [63] \\
\hline ESR1 & Estrogen receptor 1 & Dimerises with RAR and RXRA [52] \\
\hline KLF5 & $\begin{array}{l}\text { Kruppel-like factor } 5 \\
\text { (intestinal) }\end{array}$ & Binds to RARA [64] \\
\hline
\end{tabular}


TABle 2: Continued.

\begin{tabular}{|c|c|c|}
\hline Gene & Name & Relationships with vitamin A \\
\hline NPAS2 & $\begin{array}{l}\text { Neuronal PAS domain } \\
\text { protein } 2\end{array}$ & $\begin{array}{l}\text { RAR alpha and RXR alpha bind to CLOCK and NPAS2 } \\
\text { [65]. RORA target [66] }\end{array}$ \\
\hline NR1H2 & $\begin{array}{l}\text { Nuclear receptor subfamily } \\
1 \text {, group } \mathrm{H} \text {, member } 2 \text { : liver } \\
\mathrm{X} \text { receptor beta }\end{array}$ & $\begin{array}{l}\text { LXRs form obligate heterodimers with retinoid X } \\
\text { receptors RARA, RXRA, RXRB, RXRG (Entrez gene) }\end{array}$ \\
\hline PARP1 & $\begin{array}{l}\text { Poly (ADP-ribose) } \\
\text { polymerase family, member } \\
1\end{array}$ & Interacts with RARB [67] \\
\hline PIN1 & $\begin{array}{l}\text { Protein (peptidylprolyl } \\
\text { cis/trans isomerase) } \\
\text { NIMA-interacting } 1\end{array}$ & $\begin{array}{l}\text { RARalpha directly interacts with Pin } 1 \text {. Overexpression } \\
\text { of Pin1 inhibits ligand-dependent activation of } \\
\text { RARalpha [68] }\end{array}$ \\
\hline POU2F1 & POU class 2 homeobox 1 & Binds to RXR [69] \\
\hline PPARA & $\begin{array}{l}\text { Peroxisome } \\
\text { proliferator-activated } \\
\text { receptor alpha }\end{array}$ & Dimerises with RXRA and RXRG receptors [70] \\
\hline PPARG & $\begin{array}{l}\text { Peroxisome } \\
\text { proliferator-activated } \\
\text { receptor gamma }\end{array}$ & Dimerises with RXRA receptors [71] \\
\hline RXRA & Retinoid X receptor, alpha & Retinoic acid receptor \\
\hline THRA & $\begin{array}{l}\text { Thyroid hormone receptor, } \\
\text { alpha (erythroblastic } \\
\text { leukemia viral (v-erb-a) } \\
\text { oncogene homolog, avian) }\end{array}$ & Dimerises with RXRA [72] \\
\hline UBQLN1 & Ubiquilin 1 & Binds to retinoic acid receptor alpha [73] \\
\hline VDR & $\begin{array}{l}\text { Vitamin } \mathrm{D} \\
(1,25 \text {-dihydroxyvitamin } \\
\text { D3) receptor }\end{array}$ & Heterodimerises with RXR and RARG [74] \\
\hline \multicolumn{3}{|c|}{ APP and tau processing } \\
\hline APP & $\begin{array}{l}\text { Amyloid beta (A4) } \\
\text { precursor protein } \\
\text { (peptidase nexin-II, } \\
\text { Alzheimer disease) }\end{array}$ & $\begin{array}{l}\text { A gamma } 57 \text { gamma secretase cleavage product } \\
\text { suppresses retinoid signalling [75] }\end{array}$ \\
\hline BACE1 & $\begin{array}{l}\text { Beta-site APP-cleaving } \\
\text { enzyme } 1\end{array}$ & Regulated by all-trans-retinoic acid [76] \\
\hline NCSTN & Nicastrin & Blocks the effects of retinoic acid on neurogenesis [77] \\
\hline PSEN1 & $\begin{array}{l}\text { Presenilin } 1 \text { (Alzheimer } \\
\text { disease 3) }\end{array}$ & $\begin{array}{l}\text { Regulated by and regulates the effects of retinoic acid } \\
\text { on neuronal differentiation }[78,79]\end{array}$ \\
\hline PSEN2 & $\begin{array}{l}\text { Presenilin } 2 \text { (Alzheimer } \\
\text { disease 4) }\end{array}$ & Activated by all-trans-retinoic acid in osteoblasts [80] \\
\hline CDK5 & Cyclin-dependent kinase 5 & Activated by retinoic acid $[81]$ \\
\hline GSK3B & $\begin{array}{l}\text { Glycogen synthase kinase } 3 \\
\text { beta }\end{array}$ & $\begin{array}{l}\text { SH-SY5Y cells differentiate to neuron-like cells when } \\
\text { treated with Retinoic acid/BDNF leading to increases in } \\
\text { tau and tau phosphorylation, mediated primarily by } \\
\text { GSK3B [82]: GSK3B inhibitors inhibit } \\
\text { RARbeta-induced adipogenesis in mouse embryonic } \\
\text { stem cells [83]. }\end{array}$ \\
\hline MAPT & $\begin{array}{l}\text { Microtubule-associated } \\
\text { protein tau }\end{array}$ & $\begin{array}{l}\text { Phosphorylation of tau at the 12E8 (Ser-262/Ser-356) } \\
\text { epitope decreased in retinoic acid treated cells: } \\
\text { increased at Ser-195/Ser-198/Ser-199/Ser-202) and } \\
\text { (Ser-396/Ser-404) [84] }\end{array}$ \\
\hline \multicolumn{3}{|c|}{$\begin{array}{l}\text { Viral and bacterial defence RIG-1,PKR, NOD and } \\
\text { Toll receptor signalling }\end{array}$} \\
\hline CARD8 & $\begin{array}{l}\text { Caspase recruitment } \\
\text { domain family, member } 8\end{array}$ & NF \\
\hline CD14 & CD14 molecule & $\begin{array}{l}\text { Expression regulated by retinoids [85]: binds to } \mathrm{H} \text {. } \\
\text { Pylori lipopolysaccharide [86]. }\end{array}$ \\
\hline
\end{tabular}


TABle 2: Continued.

\begin{tabular}{|c|c|c|}
\hline Gene & Name & Relationships with vitamin A \\
\hline CD86 & CD86 molecule & $\begin{array}{l}\text { Expression modulated by and the viral DNA minic } \\
\text { polyriboinosinic:polyribocytidylic acid [87] }\end{array}$ \\
\hline CST3 & Cystatin C & NF antimicrobial peptide [88] \\
\hline DEFB122 & $\begin{array}{l}\text { Defensin, beta } 122 \text { : } \\
\text { Antimicrobial peptide }\end{array}$ & NF \\
\hline EIF2AK2 & $\begin{array}{l}\text { Eukaryotic translation } \\
\text { initiation factor 2-alpha } \\
\text { kinase 2: (PKR activated by } \\
\text { viral DNA) }\end{array}$ & $\begin{array}{l}\text { Upregulated by retinoic acid in HL-60 leukemia cells } \\
\text { [89] }\end{array}$ \\
\hline GBP2 & $\begin{array}{l}\text { Guanylate binding protein } \\
2 \text {, interferon inducible }\end{array}$ & NF \\
\hline MEFV & Mediterranean fever & NF \\
\hline MPO & Myeloperoxidase & $\begin{array}{l}\text { Antimicrobial peptide [88], expression regulated by } \\
\text { RXR/PPAR gamma heterodimer [90] }\end{array}$ \\
\hline PIN1 & $\begin{array}{l}\text { peptidylprolyl cis/trans } \\
\text { isomerase, } \\
\text { NIMA-interacting } 1\end{array}$ & Binds to and negatively regulates IRF3 [91] \\
\hline $\mathrm{TF}$ & Transferrin & $\begin{array}{l}\text { Antimicrobial peptide [88]. Vitamin A deficiency is } \\
\text { associated with modified iron homeostasis that can be } \\
\text { reversed by retinoid supplementation, TF contains a } \\
\text { peroxisome proliferator-activated receptor-retinoic } \\
\text { acid X receptor heterodimer binding site [92] }\end{array}$ \\
\hline TRAF2 & $\begin{array}{l}\text { TNF receptor-associated } \\
\text { factor } 2\end{array}$ & $\begin{array}{l}\text { Infection with RNA viruses activates the cytoplasmic } \\
\text { retinoic acid-inducible gene-I (RIG-I) pathway which } \\
\text { activates transcription factor IRF-3 which in turn } \\
\text { induces many antiviral genes. It also induces apoptosis } \\
\text { via TRAF2 [25] }\end{array}$ \\
\hline TLR4 & Toll-like receptor 4 & Expression suppressed by retinoic acid [93] \\
\hline PVRL2 & $\begin{array}{l}\text { Poliovirus receptor-related } \\
2 \text { (herpesvirus entry } \\
\text { mediator B) }\end{array}$ & NF: herpes simplex receptor \\
\hline ZBP1 & $\begin{array}{l}\text { Z-DNA binding protein } 1 \text { : } \\
\text { DNA-dependent activator } \\
\text { of interferon regulatory } \\
\text { factors }\end{array}$ & NF \\
\hline \multicolumn{3}{|c|}{ Cholesterol lipoprotein networks and lipid rafts } \\
\hline ABCA1 & & Retinol transporter (see above) \\
\hline ABCG1 & $\begin{array}{l}\text { ATP-binding cassette, } \\
\text { subfamily G (WHITE), } \\
\text { member } 1\end{array}$ & $\begin{array}{l}\text { Expression regulated by 9-cis retinoic acid and } \\
22 \text {-hydroxycholesterol [94] }\end{array}$ \\
\hline APOA5 & Apolipoprotein A-V & $\begin{array}{l}\text { Regulated by RORA [95]. APOA5 polymorphisms } \\
\text { modify lipoprotein bound retinyl palmitate } \\
\text { concentrations }[96]\end{array}$ \\
\hline APOC2 & Apolipoprotein C-II & Expression regulated by 9-cis-retinoic acid [97]. \\
\hline APOC3 & Apolipoprotein C-III & RORA target [43] \\
\hline APOC4 & Apolipoprotein C-IV & Expression regulated by RXR ligands [98] \\
\hline APOD & Apolipoprotein D & Expression regulated by RARA [99] \\
\hline CETP & $\begin{array}{l}\text { Cholesteryl ester transfer } \\
\text { protein, plasma }\end{array}$ & $\begin{array}{l}\text { Expression induced by } 9 \text {-cis retinoic acid (RXR agonist) } \\
{[100]}\end{array}$ \\
\hline FDPS & $\begin{array}{l}\text { Farnesyl diphosphate } \\
\text { synthase (farnesyl } \\
\text { pyrophosphate synthetase, } \\
\text { dimethylallyltranstrans- } \\
\text { ferase, } \\
\text { geranyltranstransferase) }\end{array}$ & Activated by the LXR/retinoid X receptor dimer [101] \\
\hline
\end{tabular}


TABle 2: Continued.

\begin{tabular}{|c|c|c|}
\hline Gene & Name & Relationships with vitamin A \\
\hline LPA & Lipoprotein, $\mathrm{Lp}(\mathrm{a})$ & Isotretinoin reduces LPA serum levels [102] \\
\hline LDLR & $\begin{array}{l}\text { Low-density lipoprotein } \\
\text { receptor (familial } \\
\text { hypercholesterolemia) }\end{array}$ & 皮 \\
\hline LRP1 & $\begin{array}{l}\text { Low-density } \\
\text { lipoprotein-related protein } \\
1 \text { (alpha-2-macroglobulin } \\
\text { receptor) }\end{array}$ & NF \\
\hline LRP2 & & See above (retinol receptor) \\
\hline LRP6 & $\begin{array}{l}\text { Low-density lipoprotein } \\
\text { receptor-related protein } 6\end{array}$ & Expression induced by retinoic acid [103] \\
\hline LRP8 & $\begin{array}{l}\text { Low-density lipoprotein } \\
\text { receptor-related protein } 8 \\
\text { apolipoprotein e receptor }\end{array}$ & NF \\
\hline NPC1 & $\begin{array}{l}\text { Niemann-Pick disease, type } \\
\text { C1 }\end{array}$ & NF \\
\hline NPC2 & $\begin{array}{l}\text { Niemann-Pick disease, type } \\
\text { C2 }\end{array}$ & NF \\
\hline OLR1 & $\begin{array}{l}\text { Oxidized low-density } \\
\text { lipoprotein (lectin-like) } \\
\text { receptor } 1\end{array}$ & NF \\
\hline RFTN1 & Raftlin, lipid raft linker 1 & NF \\
\hline SOAT1 & $\begin{array}{l}\text { sterol O-acyltransferase } 1: \\
\text { cholesterol acyltransferase }\end{array}$ & NF \\
\hline SREBF1 & $\begin{array}{l}\text { Sterol regulatory element } \\
\text { binding transcription } \\
\text { factor } 1\end{array}$ & Liver X receptor/RXR target [104] \\
\hline VLDLR & $\begin{array}{l}\text { Very-low-density } \\
\text { lipoprotein receptor }\end{array}$ & $\begin{array}{l}\text { All-trans retinoic acid increases expression in } \\
\text { adenocarcinoma cells [105] }\end{array}$ \\
\hline \multicolumn{3}{|c|}{ Chemokines and cytokines and inflammation } \\
\hline AGER & $\begin{array}{l}\text { Advanced glycosylation end } \\
\text { product-specific receptor }\end{array}$ & $\begin{array}{l}\text { Expression upregulated by retinol and vitamin A } \\
{[106,107]}\end{array}$ \\
\hline ALOX5 & $\begin{array}{l}\text { Arachidonate } \\
\text { 5-lipoxygenase }\end{array}$ & RORA target [108] \\
\hline CCL2 & $\begin{array}{l}\text { Chemokine (C-C motif) } \\
\text { ligand } 2\end{array}$ & $\begin{array}{l}\text { All-trans-retinoic acid suppresses bacterial } \\
\text { lipopolysaccharide-induced expression and release in } \\
\text { astrocytes [109] }\end{array}$ \\
\hline CCL3 & $\begin{array}{l}\text { Chemokine (C-C motif) } \\
\text { ligand } 3\end{array}$ & See CCL2 above \\
\hline CCR2 & $\begin{array}{l}\text { Chemokine (C-C motif) } \\
\text { receptor } 2\end{array}$ & Expression regulated by 9-cis-Retinoic acid [110] \\
\hline IL10 & Interleukin 10 & $\begin{array}{l}\text { All trans-retinoic acid increases IL10 production in } \\
\text { monocytes and macrophages [111] }\end{array}$ \\
\hline IL18 & $\begin{array}{l}\text { Interleukin } 18 \text { (interferon- } \\
\text { gamma-inducing } \\
\text { factor) }\end{array}$ & $\begin{array}{l}\text { Differentiation of SH-SY5Y neuroblastoma cells by } \\
\text { all-trans retinoic acid activates IL18 [112]. }\end{array}$ \\
\hline IL1A & Interleukin 1, alpha & $\begin{array}{l}\text { Retinoic acid decreases expression in thymic epithelial } \\
\text { cells [113] }\end{array}$ \\
\hline IL1B & Interleukin 1 , beta & $\begin{array}{l}\text { Intraperitoneal retinoic acid reduces IL- } 1 \beta, \text { IL- } 6 \text { and } \\
\text { TNF } \alpha \text { mRNA levels in the spinal cord after injury } \\
{[114] \text {. All-trans-retinoic acid increases IL1B expression }} \\
\text { in human aortic smooth muscle cells [115] }\end{array}$ \\
\hline IL33 & Interleukin 33 & $\mathrm{NF}$ \\
\hline IL6 & $\begin{array}{l}\text { Interleukin } 6 \text { (interferon, } \\
\text { beta } 2 \text { ) }\end{array}$ & $\begin{array}{l}\text { Retinoic acid increases expression in thymic epithelial } \\
\text { cells [113]. }\end{array}$ \\
\hline
\end{tabular}


Table 2: Continued.

\begin{tabular}{|c|c|c|}
\hline Gene & Name & Relationships with vitamin A \\
\hline IL8 & Interleukin 8 & $\begin{array}{l}\text { Retinoid administration decreases polymorphonuclear } \\
\text { neutrophilic leukocyte accumulation in mammary } \\
\text { alveoli activated by lipopolysaccharide, and decreases } \\
\text { IL-8 serum levels [116] }\end{array}$ \\
\hline IL1RN & $\begin{array}{l}\text { interleukin } 1 \text { receptor } \\
\text { antagonist }\end{array}$ & $\begin{array}{l}\text { Retinoic acid enhances IL-1 beta and inhibited IL-1ra } \\
\text { production in } 4 \text { beta phorbol 12beta-myristate-13alpha } \\
\text { acetate - and lipopolysaccharide-activated human } \\
\text { alveolar macrophages [117]. }\end{array}$ \\
\hline PTGS2 & $\begin{array}{l}\text { Prostaglandin- } \\
\text { endoperoxide synthase } 2 \\
\text { (prostaglandin } \mathrm{G} / \mathrm{H} \\
\text { synthase and } \\
\text { cyclooxygenase) }\end{array}$ & Suppressed by RARB [118] \\
\hline TGFB1 & $\begin{array}{l}\text { Transforming growth } \\
\text { factor, beta } 1\end{array}$ & Repressed by RXRA.PPARG dimers [119] \\
\hline TNF & $\begin{array}{l}\text { Tumor necrosis factor } \\
\text { (TNF superfamily, member } \\
\text { 2) }\end{array}$ & $\begin{array}{l}\text { LPS from bacterial pathogens activates Retinoic } \\
\text { inducible gene RIG-I which plays a key role in the } \\
\text { expression of TNF-alpha in macrophages in response to } \\
\text { LPS stimulation [120] }\end{array}$ \\
\hline FAS & $\begin{array}{l}\text { Fas (TNF receptor } \\
\text { superfamily, member 6) }\end{array}$ & $\begin{array}{l}\text { Retinoic acid increases the expression of FAS in } \\
\text { adipocytes: all-trans retinoid acid reduces FAS } \\
\text { expression in HELA cells }\end{array}$ \\
\hline
\end{tabular}

Complement and immune system

C4A

C4B

$\mathrm{CFH}$

CLU

CR1

CRP

CD33

CD36

HLA-A

HLA-A2

MICA

Oestrogen and androgen related
Complement component 4A (Rodgers blood group) Complement component 4B (Chido blood group)

Complement factor $\mathrm{H}$

Clusterin

Complement component (3b/4b) receptor 1 (Knops blood group)

C-reactive protein, pentraxin related

CD33 molecule

CD36 molecule (thrombospondin receptor)

Major histocompatibility complex, class I, A

Major histocompatibility complex, class I, A2

MHC class I

polypeptide-related sequence $\mathrm{A}$
Complement $\mathrm{C} 4$ levels correlate with those of retinol in plasma [121]

See above

Expression controlled by RAR beta [122]

See above

NF

Serum CRP levels negatively correlate with vitamin A levels [123]

NF

RORA target [61]

Upregulated by differentiation of teratoma cells into neuronal cells by retinoic acid [124]

Upregulated by interferon alpha-2b and retinoic acid combined treatment in cervical cancer cells [125]

Expression upregulated by retinoic acid in hepatic carcinoma cells [126]
AR

ESR1
Androgen receptor (dihydrotestosterone receptor; testicular feminization; spinal and bulbar muscular atrophy; Kennedy disease)

Estrogen receptor 2 (ER beta)
See above

9-cis retinoic acid stimulates expression in breast cancer cells [127] 
Table 2: Continued.

\begin{tabular}{lll}
\hline Gene & Name & Relationships with vitamin A \\
\hline & Cytochrome P450, family & \\
CYP19A1 & $\begin{array}{l}\text { 19, subfamily A, } \\
\text { polypeptide 1: aromatase: }\end{array}$ & Activated by RORA [128] \\
& $\begin{array}{l}\text { estrogen synthase } \\
\text { Hydroxysteroid (11-beta) }\end{array}$ & \\
HSD11B1 & NF \\
\hline
\end{tabular}

Growth factor networks

BDNF

CSK

FGF1

GAB2

IGF1

NTRK1

NTRK2

VEGFA

Other signalling

DKK1

DPYSL2

Homocysteine and methionine metabolism

BLMH

CBS

MSRA

MTHFD1L

MTHFR

MTR

MTRR
Brain-derived neurotrophic factor

C-src tyrosine kinase

Fibroblast growth factor 1 (acidic)

GRB2-associated binding protein 2

Insulin-like growth factor 1 (somatomedin C)

Neurotrophic tyrosine kinase, receptor, type 1

Neurotrophic tyrosine kinase, receptor, type 2 vascular endothelial growth factor $\mathrm{A}$

Dickkopf homolog 1

(Xenopus laevis)

Dihydropyrimidinase-like 2

Bleomycin hydrolase

Cystathionine-beta-

synthase

methionine sulfoxide

reductase $\mathrm{A}$

Methylenetetrahydrofolate dehydrogenase (NADP+ dependent) 1-like

5,10 -

methylenetetrahydrofolate reductase $(\mathrm{NADPH})$

5-methyltetrahydrofolatehomocysteine methyltransferase

5-methyltetrahydrofolatehomocysteine methyltransferase reductase

Paraoxonase 1
Expression regulated by RARalpha/beta and vitamin A $[129,130]$, but all-trans retinoic acid reduces BDNF and TrkB gene expression in SH-SY5Y cells [131]

CSK negatively regulates RAR functions in relation to neurite differentiation [132]

Protects fibroblasts from apoptosis induced by retinoid CD437 [133]

Gab2 silencing results in hypersensitivity to retinoic acid -induced apoptosis in neuronal cells [134]

Pulmonary expression reduced in RORalpha knockout mice [135]

Retinoic acid restores adult hippocampal neurogenesis and reverses spatial memory deficit in vitamin-A-deprived rats, partly by upregulating NTRK1 (TrkA) [136]

All-trans retinoic acid reduces BDNF and TrkB gene expression in SH-SY5Y cells [131]

Expression regulated by retinoid acid [137]

Expression regulated by retinoic acid in stem cells [103]

Upregulated in cortex and hippocampus by Vitamin A depletion [138]

Hydrolyses homocysteine thiolactone [139]

Converts homocysteine to cystathionine suppressed by all-trans-retinoic acid [140]

Regulated by retinoic acid via two promoters including RARA [141]

NF

Methylenetetrahydrofolate reductase activity is suppressed in retinol-fed rats [142]

In rats, a retinol-rich diet enhances the folate-dependent oxidation to $\mathrm{CO} 2$ of formate and histidine. The activity of hepatic methylenetetrahydrofolate reductase, which regulates liver folate metabolism, is suppressed, leading to decreased 5-methyltetrahydrofolate synthesis [142]

$\mathrm{NF}$

Hydrolyses homocysteine thiolactone [143]: vitamin A deficiency reduced serum PON1 activity in rats [144]. 
Table 2: Continued.

\begin{tabular}{|c|c|c|}
\hline Gene & Name & Relationships with vitamin A \\
\hline \multicolumn{3}{|c|}{ Oxidative stress, Iron and mitochondria } \\
\hline COX1 & $\begin{array}{l}\text { Mitochondrially encoded } \\
\text { cytochrome c oxidase I }\end{array}$ & $\begin{array}{l}\text { 9-cis retinoic acid treatment increases mitochondrial } \\
\text { DNA transcription, including ND1, ND6, and COX1 } \\
{[145]}\end{array}$ \\
\hline $\mathrm{COX} 2$ & $\begin{array}{l}\text { Mitochondrially encoded } \\
\text { cytochrome c oxidase II }\end{array}$ & Expression increased by all-trans retinoic acid [146] \\
\hline GAPDH & $\begin{array}{l}\text { Glyceraldehyde-3- } \\
\text { phosphate } \\
\text { dehydrogenase }\end{array}$ & Retinoic acid target [147] \\
\hline GSTM3 & $\begin{array}{l}\text { Glutathione S-transferase } \\
\text { M3 (brain) }\end{array}$ & Contains a retinoid X receptor-binding site [148] \\
\hline HBG2 & Hemoglobin, gamma G & $\begin{array}{l}\text { Vitamin A increases haemoglobin concentrations in } \\
\text { children [149] }\end{array}$ \\
\hline HFE & hemochromatosis & $\begin{array}{l}\text { Neuroblastoma cells carrying the C282Y HFE variant } \\
\text { do not differentiate when exposed to retinoic acid [150] }\end{array}$ \\
\hline HMOX1 & $\begin{array}{l}\text { Heme oxygenase } \\
\text { (decycling) } 1\end{array}$ & $\begin{array}{l}\text { The increase in the expression of heme oxygenase-1 } \\
\text { and the growth arrest and DNA damage-inducible } \\
\text { transcription factor } 153 \text { caused by reactive oxygen } \\
\text { species is blocked by aRARalpha-specific antagonist } \\
\text { AGN194301 in retinal epithelial cells [151] }\end{array}$ \\
\hline ND1 & $\begin{array}{l}\text { NADH dehydrogenase } \\
\text { subunit } 1\end{array}$ & $\begin{array}{l}\text { 9-cis retinoic acid treatment increases mitochondrial } \\
\text { DNA transcription, including ND1, ND6, and COX1 } \\
{[145]}\end{array}$ \\
\hline ND4 & $\begin{array}{l}\text { NADH dehydrogenase } \\
\text { subunit } 4\end{array}$ & $\begin{array}{l}\text { Upregulated by all-trans retinoic acid in neutrophils } \\
\text { [152] }\end{array}$ \\
\hline ND6 & $\begin{array}{l}\text { NADH dehydrogenase } \\
\text { subunit } 6\end{array}$ & $\begin{array}{l}\text { 9-cis retinoic acid treatment increases mitochondrial } \\
\text { DNA transcription, including ND1, ND6, and COX1 } \\
{[145]}\end{array}$ \\
\hline NFE2L2 & $\begin{array}{l}\text { Nuclear factor } \\
\text { (erythroid-derived 2)-like } 2\end{array}$ & $\begin{array}{l}\text { Inhibited by retinoic acid via RARalpha resulting in } \\
\text { lack of expression of Nrf2 target genes [153] in } \\
\text { mammary cells, but retinoic acid and } \\
\text { 12-O-tetradecanoylphorbol acetate are also able to } \\
\text { induce Nrf2 and its target gene NAD(P)H quinone } \\
\text { oxidoreductase } 1 \text { in the SH-SY5Y neuroblastoma cell } \\
\text { line [154]. }\end{array}$ \\
\hline NOS1 & $\begin{array}{l}\text { Nitric oxide synthase } 1 \\
\text { (neuronal) }\end{array}$ & Expression regulated by retinoic acid [84] \\
\hline NOS2 & $\begin{array}{l}\text { Nitric oxide synthase } 2 \text {, } \\
\text { inducible }\end{array}$ & Ditto \\
\hline NOS3 & $\begin{array}{l}\text { Nitric oxide synthase } 3 \\
\text { (endothelial cell) }\end{array}$ & Ditto \\
\hline NQO1 & $\begin{array}{l}\mathrm{NAD}(\mathrm{P}) \mathrm{H} \text { dehydrogenase, } \\
\text { quinone } 1\end{array}$ & $\begin{array}{l}\text { Retinoic acid (RA) and 12-O-tetradecanoylphorbol } \\
\text { acetats are able to induce Nrf2 and its target gene } \\
\text { NAD }(\mathrm{P}) \mathrm{H} \text { quinone oxidoreductase } 1 \text { in the SH-SY5Y } \\
\text { neuroblastomacell line [154] }\end{array}$ \\
\hline SOD2 & $\begin{array}{l}\text { Superoxide dismutase } 2 \text {, } \\
\text { mitochondrial }\end{array}$ & $\begin{array}{l}\text { All-trans-retinoic acid induces manganese superoxide } \\
\text { dismutase in a human neuroblastoma cell line [155] }\end{array}$ \\
\hline PCK1 & $\begin{array}{l}\text { Phosphoenolpyruvate } \\
\text { carboxykinase } 1 \text { (soluble) }\end{array}$ & $\begin{array}{l}\text { Three RXR-binding elements (retinoic acid response } \\
\text { element (RARE)1/PCK1, RARE2, and RARE3/PCK2) } \\
\text { are located in the promoter of Pck1 [156] }\end{array}$ \\
\hline PON2 & Paraoxonase 2 & NF \\
\hline PON3 & Paraoxonase 3 & NF \\
\hline TFAM & $\begin{array}{l}\text { Transcription factor A, } \\
\text { mitochondrial }\end{array}$ & Levels are increased by vitamin A [157] \\
\hline
\end{tabular}


Table 2: Continued.

\begin{tabular}{|c|c|c|}
\hline Gene & Name & Relationships with vitamin A \\
\hline \multicolumn{3}{|l|}{ Heat shock } \\
\hline DNAJC28 & $\begin{array}{l}\text { DnaJ (Hsp40) homolog, } \\
\text { subfamily C, member } 28\end{array}$ & NF \\
\hline HSPA1B & $\begin{array}{l}\text { Heat shock } 70 \mathrm{kDa} \text { protein } \\
\text { 1B }\end{array}$ & NF \\
\hline HSPA5 & $\begin{array}{l}\text { Heat shock } 70 \mathrm{kDa} \text { protein } \\
5 \text { (glucose-regulated } \\
\text { protein, } 78 \mathrm{kDa})\end{array}$ & $\begin{array}{l}\text { Endoplasmic reticulum stress is increased in } \\
\text { hepatocarcinoma cells by all-trans retinoic acid, } \\
\text { characterised by increased expression of HSPA5 } \\
\text { (grp78), GADD153, and XBP1[158] }\end{array}$ \\
\hline \multicolumn{3}{|c|}{ Monoamine networks } \\
\hline ADRB1 & $\begin{array}{l}\text { Adrenergic, beta-1-, } \\
\text { receptor }\end{array}$ & RARA target [159] \\
\hline ADRB2 & $\begin{array}{l}\text { Adrenergic, beta-2-, } \\
\text { receptor, surface }\end{array}$ & Expression regulated by all-trans retinoic acid [160] \\
\hline COMT & $\begin{array}{l}\text { Catechol-O- } \\
\text { methyltransferase }\end{array}$ & Expression stimulated by all-trans retinoic acid [161] \\
\hline PNMT & $\begin{array}{l}\text { Phenylethanolamine } \\
\text { N-methyltransferase }\end{array}$ & $\begin{array}{l}\text { Retinoic acid differentiates embryonic carcinoma cells } \\
\text { into neuronal cells, } 70 \% \text { of which stain for tyrosine } \\
\text { hydroxylase, dopamine beta-hydroxylase, and } \\
\text { phenylethanolamine N-methyltransferase [162]. }\end{array}$ \\
\hline \multicolumn{3}{|l|}{ Cholinergic } \\
\hline CHAT & Choline acetyltransferase & Expression controlled by retinoic acid [163] \\
\hline CHRNA3 & $\begin{array}{l}\text { Cholinergic receptor, } \\
\text { nicotinic, alpha } 3\end{array}$ & Expression increased by retinoid acid [164] \\
\hline CHRNA4 & $\begin{array}{l}\text { Cholinergic receptor, } \\
\text { nicotinic, alpha } 4\end{array}$ & Expression decreased by retinoic acid [164] \\
\hline CHRNB2 & $\begin{array}{l}\text { Cholinergic receptor, } \\
\text { nicotinic, beta } 2 \text { (neuronal) }\end{array}$ & Expression increased by retinoid acid [164] \\
\hline
\end{tabular}

Neuropeptide

GRN Granulin

Adhesion and proteoglycans

ACAN

ICAM1

\section{Aggrecan}

Intercellular adhesion molecule 1 (CD54), human rhinovirus receptor

\section{Structural, dynamins, and kinesins}

COL11A1

DSC1

LMNA

Ubiquitin

UBD

UBE2I

DNA repair

$\mathrm{XRCC1}$
Collagen, type XI, alpha 1

Desmocollin 1

Lamin A/C (nuclear)
All-trans retinoic acid increases expression in myeloid cells [165]

Expression modulated by 13 -cis retinoic acid in fibroblasts [166]

All-trans retinoic acid downregulates ICAM1 expression in bone marrow stromal cells [167] 
Table 2: Continued.

\begin{tabular}{|c|c|c|}
\hline Gene & Name & Relationships with vitamin A \\
\hline \multicolumn{3}{|c|}{ Cell cycle and tumour } \\
\hline CDC2 & $\begin{array}{l}\text { Cell division cycle } 2, \mathrm{G} 1 \text { to } \\
\mathrm{S} \text {, and } \mathrm{G} 2 \text { to } \mathrm{M}\end{array}$ & Activated by retinoic acid [173] \\
\hline \multicolumn{3}{|c|}{ Miscellaneous metabolism } \\
\hline ACAD8 & $\begin{array}{l}\text { Acyl-coenzyme A } \\
\text { dehydrogenase family, } \\
\text { member } 8\end{array}$ & $\begin{array}{l}\text { Catalyzes the dehydrogenation of acyl-CoA derivatives } \\
\text { in the metabolism of fatty acids or branch chained } \\
\text { amino acids. The encoded protein is a mitochondrial } \\
\text { enzyme that functions in catabolism of the } \\
\text { branched-chain amino acid valine. }\end{array}$ \\
\hline ALDH18A1 & $\begin{array}{l}\text { Aldehyde dehydrogenase } 18 \\
\text { family, member A1 }\end{array}$ & $\begin{array}{l}\text { NF the encoded protein catalyzes the reduction of } \\
\text { glutamate to delta1-pyrroline-5-carboxylate, a critical } \\
\text { step in the de novo biosynthesis of proline, ornithine } \\
\text { and arginine. }\end{array}$ \\
\hline ARSA & $\begin{array}{l}\text { Arylsulfatase A: hydrolyzes } \\
\text { cerebroside sulfate to } \\
\text { cerebroside and sulphate }\end{array}$ & $\begin{array}{l}\text { Increased urinary excretion of both arylsulfatases A and } \\
\mathrm{B} \text { is increased in cases of severe vitamin A deficiency } \\
\text { coupled with malnutrition [174] }\end{array}$ \\
\hline ELAVL4 & $\begin{array}{l}\text { ELAV (embryonic lethal, } \\
\text { abnormal vision, } \\
\text { drosophila)-like } 4(\mathrm{Hu} \\
\text { antigen } \mathrm{D})\end{array}$ & $\begin{array}{l}\text { Inhibition reduces retinoic acid-induced neuronal } \\
\text { differentiation of mouse embryonal carcinoma P19 } \\
\text { cells [175] }\end{array}$ \\
\hline SGPL1 & $\begin{array}{l}\text { Sphingosine-1-phosphate } \\
\text { lyase } 1\end{array}$ & $\begin{array}{l}\text { Treatment of F9 embryonal carcinoma cells with } \\
\text { retinoic acid induces differentiation to primitive } \\
\text { endoderm (PrE). This effect is attenuated by SGPL1 } \\
\text { knockout [176]. }\end{array}$ \\
\hline \multicolumn{3}{|c|}{ Miscellaneous } \\
\hline CELF2 & $\begin{array}{l}\text { CUGBP, Elav-like family } \\
\text { member } 2\end{array}$ & Splicing regulated by retinoic acid [177] \\
\hline CUBN & $\begin{array}{l}\text { Cubilin (intrinsic } \\
\text { factor-cobalamin receptor) }\end{array}$ & Expression regulated by all-trans-retinoic acid [178] \\
\hline F13A1 & $\begin{array}{l}\text { Coagulation factor XIII, A1 } \\
\text { polypeptide }\end{array}$ & $\begin{array}{l}\text { Vitamin A reduces factor XIII levels in rats fed an } \\
\text { atherogenic diet [179]. }\end{array}$ \\
\hline HHEX & $\begin{array}{l}\text { Hematopoietically } \\
\text { expressed homeobox }\end{array}$ & $\begin{array}{l}\text { All-trans retinoic acid enhances expression in normal } \\
\text { and tumorous mammary tissue }[180]\end{array}$ \\
\hline NEDD9 & $\begin{array}{l}\text { Neural precursor cell } \\
\text { expressed, developmentally } \\
\text { downregulated } 9\end{array}$ & $\begin{array}{l}\text { Downstream target of all-trans retinoic acid and its } \\
\text { receptors in the human SH-SY5Y neuroblastoma cell } \\
\text { line [181] }\end{array}$ \\
\hline RELN & Reelin & $\begin{array}{l}\text { Retinoic acid-induced differentiation of NT2 cells to } \\
\text { hNT neurons increases reelin expression [182]. }\end{array}$ \\
\hline RNR1 & RNA, ribosomal 1 & NF \\
\hline RPS3A & Ribosomal protein S3A & $\begin{array}{l}\text { Downregulated by retinoid-induced differentiation of } \\
\text { HL- } 60 \text { cells }[183]\end{array}$ \\
\hline RUNX1 & $\begin{array}{l}\text { Runt-related transcription } \\
\text { factor } 1 \text { (acute myeloid } \\
\text { leukemia } 1 \text {; aml1 } \\
\text { oncogene) }\end{array}$ & $\begin{array}{l}\text { RUNX1 knockdown inhibits retinoid-induced } \\
\text { differentiation of HL- } 60 \text { myeloid leukaemia cells [184]. }\end{array}$ \\
\hline SEPT3 & Septin 3 & $\begin{array}{l}\text { Expressed in SH-SY5Y, after retinoic acid-induced } \\
\text { differentiation [185] }\end{array}$ \\
\hline SNCA & $\begin{array}{l}\text { Synuclein, alpha (non-A4 } \\
\text { component of amyloid } \\
\text { precursor) }\end{array}$ & $\begin{array}{l}\text { Vitamin A, beta-carotene and coenzyme Q10 inhibit } \\
\text { the formation of synuclein fibrils [186] }\end{array}$ \\
\hline SYN3 & Synapsin III & $\begin{array}{l}\text { Synapsins including SYN3 are upregulated by retinoic } \\
\text { acid-induced differentiation of NTera-2cl.D1 cells [187] }\end{array}$ \\
\hline TARDBP & TAR DNA binding protein & $\mathrm{NF}$ \\
\hline VCP & Valosin-containing protein & $\begin{array}{l}\text { Retinoic acid receptor responder (RARRES1) regulates } \\
\text { VCP expression in human prostatic epithelial cells } \\
{[188]}\end{array}$ \\
\hline
\end{tabular}


their respective genes and risk factors, any of which can lead to beta-amyloid deposition in multifarious ways. Each risk factor can act independently of any gene or other risk factor variant, in animal models - as with the fox. This in turn might suggest that it is not the risk promoting polymorphisms in the Alzheimer's disease patients that are crucial, as the risk factors can in any case promote beta-amyloid deposition, but the equivalent polymorphisms in the control group, that are providing protection; a subtle distinction that awaits characterisation of the functional effects of many different gene variants. The reasoning also suggests that betaamyloid deposition is the consequence and not the cause of the many factors able to promote Alzheimer's disease. Anoxia, ischaemia, hypoglycaemia, hypercholesterolaemia, and vitamin A deficiency are all able to kill neurones, in some cases including cholinergic neurones, without the aid of beta amyloid.

\subsection{Low Incidence of Alzheimer's Disease and Protective Fac-} tors. In relation to Alzheimer's disease, there is an island where longevity is increased, related to the nun study [231234]. Nuns do not have children, (the number of pregnancies is a risk factor in Alzheimer's disease [235]), do not consume high concentrations of saturated fats (low cholesterol), and are unlikely to have sexually transmitted diseases or viral and other common pathogen diseases vectored by childhood infections (Herpes and chlamydia, inter alia). Their vitamin A levels and general health are sustained by a healthy diet, regular fish on Fridays, and exercise.

There are few strategies that have been shown to reduce the severity of Alzheimer's disease, once established. It has, however, been shown that Helicobacter pylori elimination increases the cognitive abilities and the lifespan of Alzheimer's disease patients [236]. In addition, two separate case reports have shown complete reversal of dementia in two patients diagnosed with Alzheimer's disease, by identification and eradication of the fungal pathogen Cryptococcus Neoformans [237, 238].The TNF antagonist, etanercept, has also been reported to produce a striking remedial effect on symptomatology, following perispinal application [239]. However, the use of TNF antagonists is also associated with an increased incidence of opportunistic bacterial, fungal, and viral infestations, including cytomegalovirus, and cryptococcal infections [240], perhaps a contraindication for their prolonged use.

A number of epidemiological studies have shown that the incidence of Alzheimer's disease can be reduced, although, once the disease is established, there is little evidence for any curative effects of any treatment other than the above. These protective factors are in most cases the obverse of the risk factors and include diets rich in fish or polyunsaturated fatty acids [241, 242], the Mediterranean diet [243] and the use of statins [244], which are counter to the effects of high cholesterol. A diet rich in fruit and vegetables is associated with reduced dementia incidence [245] and is able to sustain Vitamin A levels and reduce homocysteine levels in the elderly population [246]. High folate intake, which reduces homocysteine levels [247], and the use of nonsteroidal antiinflammatories have also been reported to reduce risk [248].
Again these are related to the risk factors and to the genes, which may condition their success (cf. Vitamin E).

3.5. Relevance of These Factors to the Genes Identified in Genome-Wide Association Studies. Four major genes have been discovered prior to and from GWAS studies, APOE4, clusterin, complement receptor 1 , and PICALM $[6,249]$. The close relationships between these genes and herpes simplex infection have been the subject of a previous article [226]. APOE4 also favours the binding of C. Pneumoniae elementary bodies to host cells [250]. It is also a risk factor for hypercholesterolaemia, per se [251], and for carotid artery atherosclerosis in men with diabetes [252]. APOE4 is also the isoform least able to promote lipid efflux from neuronal cells [253], a factor that may enhance the cholesterol dependent cleavage of beta-amyloid by beta and gamma secretase [254]. It is also the least able isoform binding the vitamin A precursor retinyl palmitate [255] (see below). Complement receptor 1 is a pathogen receptor for both herpes simplex [256], and C. Neoformans [257] and also for the atherogenic pathogen, $P$. Gingivalis [258], a key cause of periodontitis/gum disease, which has also been implicated as a risk factor in dementia [259]. Both Helicobacter pylori and C. Pneumoniae [260] use the mannose-6-phosphate IGF2 receptor (inter alia) for entry. This binds to clusterin and its endocytosis is controlled by PICALM [226]. PICALM (phosphatidylinositol binding clathrin assembly protein), as its name implies, is involved in clathrin-mediated endocytosis [261], a process used by C. Pneumoniae to gain cellular entry [262], for the internalisation of herpes simplex glycoprotein D [263] or the cytomegalovirus chemokine receptor [264] and for the uptake of outer membrane vesicles from certain strains of $H$. pylori, into gastric epithelial cells [265]. Clathrin also associates with HHV-6 virions [266]. Clusterin is an inhibitor of the membrane attack complex that is inserted into microbial membranes causing death by lysis [267]. It is also a ligand for the retinol/lipoprotein receptor LRP2 [268], and the gene contains a retinoid response element (Table 2). Thus it would seem that the key role of these genes may be related to their ability to target multiple aspects of diverse risk factor networks.

3.6. Relationships between Risk Factors and a Key Role for Herpes Simplex Activation (Figure 1). Hypercholesterolaemia can evidently be related to other dietary risk factors such as saturated fat consumption, and to atherosclerosis. Docosahexaenoic acid increases total plasma cholesterol levels in hymans, but only in APOE4 carriers, an effect that may negate the cardioprotective effects of fish oil supplementation [269]. Helicobacter pylori infection also causes malabsorption of vitamin B12 and folate, leading to increased homocysteine levels, that can be restored by H. pylori eradication [270]. Homocysteine metabolism is also related to glutathione synthesis via the transsulfuration pathway (homocysteine $\rightarrow$ cysteine $\rightarrow$ glutathione). Increased levels of homocysteine and reduced levels of glutathione in Alzheimer's disease suggest impairments in the transsulfuration pathway [271]. Glutathione is a potent antiviral and 


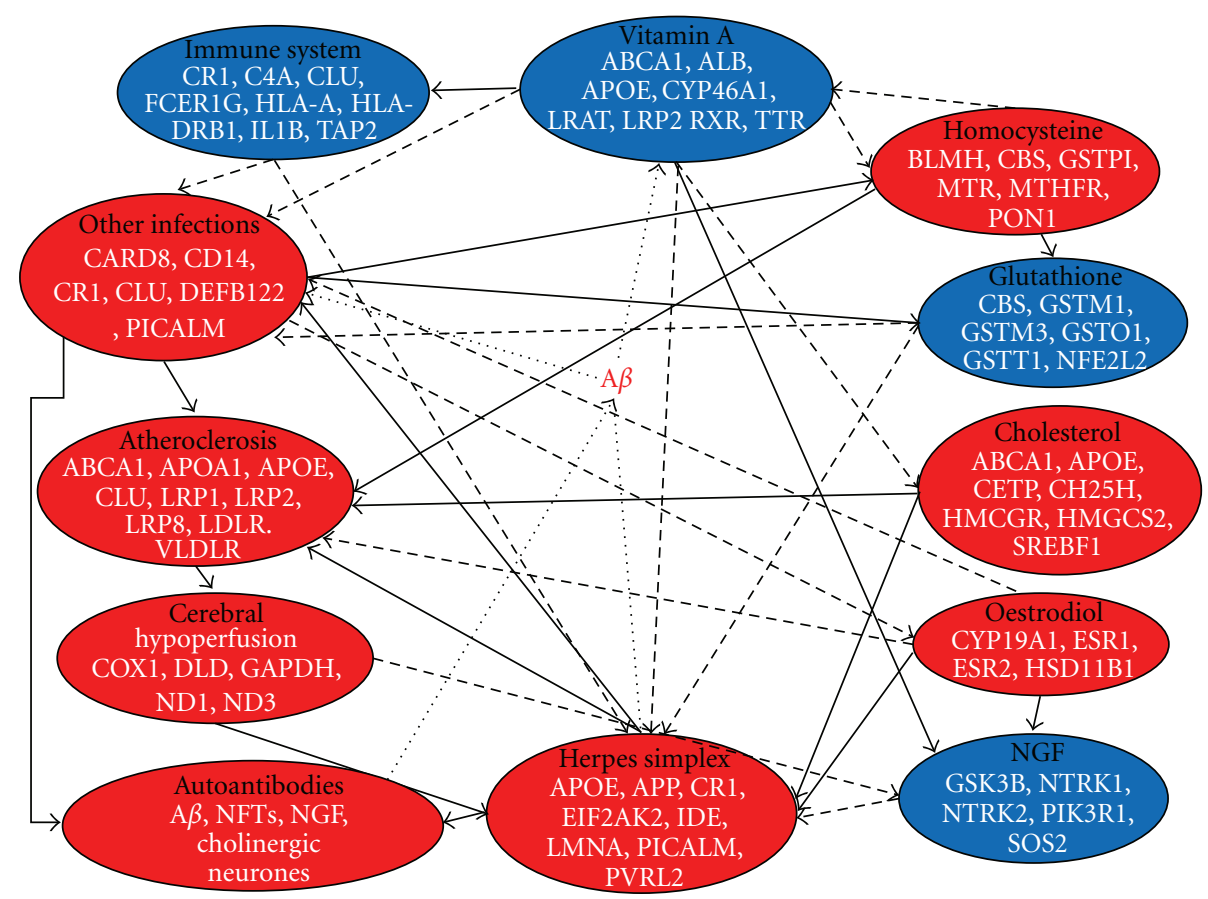

FIGURE 1: An environmental risk factor-gene interactome in Alzheimer's disease. Risk factors diminished in Alzheimer's disease (vitamin A deficiency, NGF levels, immune competence, and glutathione depletion) are shown in blue and those increased in red. Solid lines indicate a positive, and dashed or dotted lines a negative effect of risk factor $\mathrm{X}$ on risk factor Y. All risk factors feed into increased beta-amyloid deposition. A selection of susceptibility genes relevant to each process is shown (see Table 2 and http://www .polygenicpathways.co.uk/alzpolys.html.

bactericidal agent with effects targeted at herpes simplex and C. Pneumoniae, inter alia both of which also diminish glutathione levels in infected cells [27, 272, 273]. H. pylori expresses an enzyme, gamma-glutamyltranspeptidase that enables it to metabolise the host's extracellular glutamine and glutathione which are hydrolysed to glutamate, which is fed into the H. pylori Krebs cycle, resulting in diminished glutathione levels that can be restored by $\mathrm{H}$. pylori elimination [27, 273]. Glutathione levels are reduced in Alzheimer's disease and many others [274].

In both coronary artery disease and carotid artery atherosclerosis, high plasma levels of homocysteine are positively correlated with $C$. Pneumoniae seropositivity suggesting a role for the bacterium in promoting high homocysteine levels. [275, 276]. Indeed carotid artery atherosclerosis is correlated with antibodies to C. Pneumoniae, and to a lesser extent with antibodies to $H$. pylori, but in this case, only in individuals with low social status [277].

The growth of C. Neoformans is attenuated by diethylstilbestrol and oestradiol but not by progesterone or testosterone [278]. Helicobacter pylori adsorbs a number of steroids including pregnenolone and two androgens (dehydroepiandrosterone and epiandrosterone and 3-hydroxylated oestrogens (oestrone and oestradiol). These are glucosylated and the glucosyl-steroid hormone derivatives used as membrane lipid components [279]. Oestradiol, androstenedione, and progesterone are all able to inhibit the growth of H. pylori [280].
These complex interactions, of which there are likely many more, suggest that in addition to epistasis and geneenvironment interactions, environment-environment interactions have to be factored in to an already complex equation (cf. vitamin E).

Factors known to reactivate herpes simplex include heat [281], 17-beta oestradiol [282] and the inflammatory cytokine interleukin 6 [283] where a role for corticosterone has been proposed [284]. NGF deprivation [285] also reactivates the virus and NGF promotes viral latency via the TrkA receptor [286] (cf. neurotrophin signalling). Vitamin A supplementation in rats increases the cerebral levels of both NGF and BDNF [129] while oestrogen deficiency lowers cerebral NGF levels, an effect reversed by 17-beta oestradiol [287]. Transient cerebral ischaemia lowers NGF levels [288]. Hypoxia is also able to increase the replication of herpes simplex [289].

Fevers induced by diverse infections might thus be expected to reactivate herpes simplex, as well as cerebral hypoperfusion. IL6 plasma and CSF levels have been reported to be increased in Alzheimer's disease and the secretion of IL6 from monocytes is increased [290-292]. IL6 plasma levels are raised by infection with C. Pneumoniae [293] or Helicobacter pylori [294], and IL6 production in monocytes is stimulated by C. Neoformans [295]. Cortisol levels are also increased in the ageing population and in Alzheimer's disease [296, 297]. High levels of total oestradiol have been reported as a risk factor for Alzheimer's disease in both women and men $[223,224]$. 
As so many other risk factors seem able to reactivate the virus, this may be a key precipitant for the final curtain. Herpes simplex viral DNA is present in Alzheimer's disease plaques [298], and the plaques and tangles in Alzheimer's disease contain a very high proportion of herpes simplex interacting proteins, as well as immune-related components. The presence of the complement membrane attack complex in neurones suggests that the neuronal destruction in Alzheimer's disease might well be related to the consequences of battle between the virus and the immune network that has eliminated the virus at a terrible cost of collateral neuronal damage [33]. IgM+ antibodies, which preferentially index HSV-1 reactivation, have been shown to be able to predict the future risk of developing Alzheimer's disease [208], and the ability of other risk factors, particularly other infections, to reactivate the virus suggests a complex interplay of genes and risk factors that funnel towards viral reactivation and plaque and tangle formation.

3.7. The Importance of Vitamin A. Low vitamin A levels are a problem in the ageing population, and even in successfully ageing persons can be observed in $50 \%$ of the population over the age of 80-85 [299] (cf. the fox). Low vitamin A levels are also a risk factor for Alzheimer's disease [225]. Vitamin A plays an important role in maintaining the immune system [300], many genes of which are implicated in Alzheimer's disease. APP is involved in the vitamin A arena, as a gamma57 gamma secretase cleavage product suppresses retinoid signalling [75].

The vitamin A derivative, retinoic acid, inhibits herpes simplex replication $[301,302]$ as well as chlamydial infection and growth [303]. Vitamin A also stunts the growth of Helicobacter pylori [304]. The effects of vitamin A on C. Neoformans do not appear to have been examined. However, glucuronoxylomannan, the polysaccharide component of the capsular material of cryptococcus neoformans, exhibits potent immunosuppressive properties. This compound downregulates TNF-alpha and IL-1beta, and upregulates the inhibitory cytokine IL-10, but also inhibits retinoic receptor (RORG) synthesis [305]. Retinoic acid is also able to lower plasma homocysteine levels via the induction of hepatic glycine $\mathrm{N}$-methyltransferase. Homocysteine in contrast inhibits retinoic acid synthesis [306, 307].

Vitamin A levels are in fact higher in hypercholesterolemia patients [308]. This may perhaps be due to the fact that retinyl palmitate, the vitamin A precursor, like cholesterol, is also transported by lipoproteins in the blood, mainly in the VLDL fraction (which primarily consist of APOC2/APOE) and the LDL fraction (which primarily consists of APOB) [41]. Retinyl palmitate concentrations in the blood are affected by APOE polymorphisms and radiolabelled retinyl palmitate binding in total plasma and nonchylomicron fractions is least in APOE4+/+ carriers [255]. The aortic concentrations of triglycerides, total cholesterol, free and esterified cholesterol, and phospholipids are increased in vitamin A deficient rats, an effect reversed by vitamin A supplementation [144]

A large number of Alzheimer's disease genes are related to vitamin A (Table 2), and an even larger number responsive to retinoic acid via the action of RAR or RXR transcriptional control.

3.8. Autoantibodies to the Antimicrobial Peptide Beta Amyloid: Likely Derivation from Antibodies to Pathogens. Beta-amyloid is a potent antimicrobial peptide. Although not tested against C. Neoformans, H. pylori, or C. Pneumoniae, it was found to have broad spectrum activity against a variety of yeasts and bacteria, effects that were attenuated by anti-A $\beta$ antibodies. [309]. Lactotransferrin is also an antimicrobial peptide that colocalises to plaques and tangle in the Alzheimer's disease brain [310] and other antimicrobial peptides include the susceptibility gene products cystatin C, defensin DEFB122, myeloperoxidase, and transferrin [88]. beta-amyloid, like acyclovir, also attenuates the stimulatory effects of HSV1 on miRNA-146a levels in neuronal cells [311]. The antimicrobial and antiviral properties of beta amyloid are, however, likely to be abrogated by the presence of betaamyloid antibodies in the sera of the ageing population [312] and in Alzheimer's disease [313].

As shown in Table 3, a number of pathogens implicated in Alzheimer's disease or its attendant risk factors, express proteins with a high degree of homology to betaamyloid. These include proteins from HSV-1, HHV-6, the cytomegalovirus, C. Neoformans, $H$. pylori, C. Pneumoniae, B. Burgdorferi and, P. Gingivalis. Antibodies to B. Burgdorferi [314] and C. Pneumoniae [210] and Herpes simplex and HHV-6 viral DNA [298, 315] have all been reported in or around Alzheimer's disease plaques, and antibodies to $H$. pylori recovered from Alzheimer's disease serum and cerebrospinal fluid [316]. A recent study showed that P. Gingivalis antibodies, cross-reactive with human HSP60, were observed in $100 \%$ of a sample of 20 atherosclerosis patients [317]. The immune system is not designed to raise antibodies to a selfprotein, and this high degree of homology suggests that the autoantibodies to beta-amyloid are created by antibodies to homologous pathogens' proteins.

Several other autoantibodies have been reported in Alzheimer's disease, including targets such as nerve growth factor [318], cholinergic neurones [319], the choroid plexus [320], and neurofibrillary tangles, inter alia [321]. The very extensive sharing of viral and bacterial protein sequences with the human proteome [230, 322-324] suggests that these too might be derived from cross-reactive microbial antigens. Again the ability to create autoantibodies is conditioned by genes, particularly HLA-antigens [325, 326]. Autoantibodies are often regarded as an epiphenomenon, but their ability to traverse the blood-brain barrier [327], and the recent recognition of their ability to enter cells [328] casts them in a new light as pathological immunopharmacological agents able to block the function of their target proteins: this has indeed been shown for Alzheimer's disease-derived ATP synthase autoantibodies which block ATP synthesis and cause apoptosis in neuroblastoma cells [329].

\section{Summary}

The classical population genetics example of the foxes and rabbits illustrates how genes and risk factors can differentially 
TABLE 3: Viral, bacterial, and fungal protein homology with beta-amyloid; beta-amyloid segments were compared with Borrelia Burgdorferi, C. Neoformans, C. Pneumoniae, H. Pylori, P. Gingivalis, and herpes viruses (HSV1, HHV6, and cytomegalovirus) proteomes by BLAST analysis. The B cell and T cell antigenicity indices are shown, and those above the server set threshold of 0.35 (B cell epitope) or 0.5 ( $\mathrm{T}$ cell epitope) are highlighted in bold. The first column shows the amino acid sequence of beta-amyloid ${ }_{1-42}$ and the alignments with pathogen proteins are shown. Spaces represent nonidentical amino acids and + signs amino acids with similar physicochemical properties. Only highly antigenic regions of pentapeptides or more were processed. The VGGVV sequence, antibodies to which label beta-amyloid in brain tissue, despite relatively low antigenicity, has already been reported to be identical to proteins expressed by 69 viruses including HSV-1, HSV-2, and HHV6 [230].

\begin{tabular}{|c|c|c|c|}
\hline & B cell & $\mathrm{T}$ cell & Alignments \\
\hline $\mathrm{D}$ & 0.41 & 0.04 & $\begin{array}{l}\text { +AE HDSG+ C. Neoformans DAE F H+SG EV Borrelia burgdorferi DAEF H. Pylori DA } \\
\text { FRH H. Pylori +AE RH HSV-1 D FR DS HHV-6 +AEFR P. Gingivalis DA EFRHD and } \\
+ \text { AEFR +SG C. Pneumoniae }\end{array}$ \\
\hline A & 0.35 & 0.78 & $\begin{array}{l}\text { AEFR D GY+V C. Neoformans AEF D S YE H. pylori AE+RH+ H. pylori AEF H+ Borrelia } \\
\text { burgdorferi AEFR HD Cytomegalovirus AE R SG HSV-1 AE+ HD HHV-6 A+F H+S and } \\
\text { AEFR P. Gingivalis AEF DSG C. Pneumoniae }\end{array}$ \\
\hline E & 0.62 & 0.02 & $\begin{array}{l}\text { EFRHD H. Pylori EF DSG HHV-6 EFR DS Borrelia Burgdorferi EF R DS YE C. Neoformans } \\
\text { E R DSGY V P. Gingivalis EF SGYEV C. Pneumoniae }\end{array}$ \\
\hline $\mathrm{F}$ & 0.73 & 0.93 & $\begin{array}{l}\text { FRHDS C. Neoformans +RH SGY++ Borrelia burgdorferi F HD EV H. Pylori F H+SG H. } \\
\text { Pylori FR SGY Cytomegalovirus +RHDS P. Gingivalis F H+SGY C. Pneumonia }\end{array}$ \\
\hline $\mathrm{R}$ & 0.85 & 0.05 & $\begin{array}{l}\text { R D GYEV C. Neoformans R SGYE H. pylori RHDS Y V H. pylori RH+ GY Borrelia } \\
\text { burgdorferi RHDSG Cytomegalovirus RHD YE cytomegalovirus RH SG HSV-1 RHDS } \\
\text { HHV-6 R+DS Y+ P. Gingivalis }\end{array}$ \\
\hline $\mathrm{H}$ & 0.57 & 0.14 & $\begin{array}{l}\text { HDSGY C. Neoformans HD G EV H. pylori +DSGY H. pylori H+SG Y+V Borrelia } \\
\text { burgdorferi H+SG HSV-1 HDSG P. Gingivalis ++SGY+V C. Pneumoniae }\end{array}$ \\
\hline $\mathrm{D}$ & 0.69 & 0.03 & $\begin{array}{l}\text { DSGY+V C. Neoformans +SG+EV H. pylori DSGY HSV-1 DSG+EV P. Gingivalis DSGY V } \\
\text { C. Pneumoniae }\end{array}$ \\
\hline S & 0.38 & 0.02 & SGYEV P. Gingivalis SGYE H. pylori SGY++ C. Neoformans SG+EV C. Pneumoniae \\
\hline G & 0.63 & 0.04 & $\begin{array}{l}\text { GYEVH H. pylori GYE V KL+ Borrelia Burgdorferi GYE LV and GY++ + LV C. } \\
\text { Neoformans GYEV P. Gingivalis GYEV and GY HH C. Pneumoniae }\end{array}$ \\
\hline Y & 0.56 & 0.96 & $\begin{array}{l}\text { YE HH and YE+ HQ and Y++H Q and YE HHQ H. pylori YEVH Cytomegalovirus YE+ KL } \\
\text { Borrelia Burgdorferi YE + QK FC. Neoformans Y++H H+K P. Gingivalis Y+V +Q LV C. } \\
\text { Pneumoniae }\end{array}$ \\
\hline $\mathrm{E}$ & 0.58 & 0.02 & $\begin{array}{l}\text { EV +QK H. pylori EV HQ L Cytomegalovirus EV +KL Borrelia Burgdorferi EV Q LV C. } \\
\text { Neoformans EV KLV P. Gingivalis EV QKLV C. Pneumoniae }\end{array}$ \\
\hline V & 0.35 & 0.90 & $\begin{array}{l}.+ \text { H QK H. pylori V HQ LV Cytomegalovirus VH QK+V HHV-6 VH KL Borrelia } \\
\text { Burgdorferi +HH LV C. Neoformans VH + LV P. Gingivalis V HQKL C. Pneumoniae }\end{array}$ \\
\hline $\mathrm{H}$ & -0.17 & 0.10 & HHQK H. pylori and C. Pneumoniae HH KL Cytomegalovirus HH KL P. Gingivalis \\
\hline $\mathrm{H}$ & -0.66 & 0.11 & HQKL+ Borreli Burgdorferi HQKL C. Pneumoniae and HSV-1 +QKLV P. Gingivalis \\
\hline Q & -1.03 & 0.03 & QKLV C. Neoformans and P. Gingivalisand C. Pneumoniae \\
\hline $\mathrm{K}$ & -1.47 & 0.93 & $\begin{array}{l}\text { KLVFF H. pylori: Cryptococcus neoformans Borrelia Burgdorferi Chlamydophila } \\
\text { pneumoniae KLVF Human herpesvirus } 1\end{array}$ \\
\hline $\mathrm{L}$ & -1.34 & 0.95 & LVFF Human herpesvirus 5: Human herpesvirus 6 \\
\hline $\mathrm{V}$ & -1.20 & 0.68 & \\
\hline $\mathrm{F}$ & -0.93 & 0.69 & \\
\hline $\mathrm{F}$ & -0.98 & 0.74 & \\
\hline A & -0.82 & 0.05 & \\
\hline $\mathrm{E}$ & -0.31 & 0.05 & \\
\hline $\mathrm{D}$ & 0.23 & 0.11 & \\
\hline V & 0.81 & 0.88 & $\begin{array}{l}\text { VGSNK Borrelia burgdorferi Cryptococcus neoformans Porphyromonas gingivalis }+ \text { GSNK } \\
\text { Cytomegalovirus VGSN Helicobacter pylori Chlamydophila pneumoniae }\end{array}$ \\
\hline G & 1.24 & 0.03 & GSNK Helicobacter Pylori Chlamydophila pneumoniae \\
\hline $\mathbf{S}$ & 1.22 & 0.03 & \\
\hline $\mathbf{N}$ & 0.90 & 0.03 & \\
\hline K & 0.36 & 0.30 & \\
\hline G & 0.30 & 0.10 & \\
\hline
\end{tabular}


Table 3: Continued.

\begin{tabular}{llll}
\hline & B cell & T cell & Alignments \\
\hline A & -0.24 & 0.05 & \\
I & -0.58 & 0.07 & \\
I & -1.00 & 0.13 & \\
G & -1.14 & 0.03 & \\
L & -1.19 & $\mathbf{0 . 7 2}$ & \\
M & -1.23 & 0.13 & VGGVV 69 viruses/phages \\
V & -1.16 & 0.23 & \\
G & -0.97 & 0.03 & \\
G & -1.02 & 0.03 & \\
V & -0.63 & 0.23 & \\
V & -0.45 & 0.33 \\
I & -0.80 & $\mathbf{0 . 9 5}$ \\
A & -1.06 & $\mathbf{0 . 8 3}$ & \\
\hline
\end{tabular}

permit or disallow the effects of a causative agent, depending on a permutation of circumstance. Applying this model to Alzheimer's disease also suggests that many of the environmental risk factors in Alzheimer's disease are in fact causative agents, at least in terms of an ability to produce beta-amyloid deposition, per se, as shown in nontransgenic animal models. Their effects are also clearly related to other risk factors and genes. This would infer that the susceptibility genes in Alzheimer's disease permit the actions of these agents but, perhaps more importantly, that polymorphisms in the control population do not. Functional characterisation of these control variants may provide important clues to overall methods of protection.

Many of these risk factors are avoidable or amenable to therapy. Diet is already known to be an important risk/ protective factor with regard to the incidence of Alzheimer's disease. For example there is clear evidence that the omega3 fatty acid docosahexaenoic acid (DHA), a component of fish and the Mediterranean diet, also protective factors $[243,330]$, is associated with a reduced risk of dementia [331], although a recent study with DHA in mild to moderate Alzheimer's disease, failed to show disease arrest or diminution [332]. However, in agreement with epidemiology, DHA significantly benefited two measures of cognition in mild to moderate non-ApoE4 carriers [333]. High vitamin A and low homocysteine levels are related to a high intake of fruit and vegetables in elderly patients [246]. Fruit and vegetable juice consumption is also associated with reduced Alzheimer's disease incidence [334].

Given the fact that the potential causes of Alzheimer's disease appear to be multifactorial, perhaps a multifactorial therapeutic effort is also needed. Such approaches might include a greater attention to diet, homocysteine and cholesterol levels, vitamin A supplementation where necessary, and the regular detection and elimination of herpes simplex, B. Burgdorferi, C. Pneumoniae, H. pylori, C. Neoformans, and other pathogens in the ageing population. The removal of beta-amyloid antibodies and of others prevalent in Alzheimer's disease might also be of benefit. These are simple preventive measures, requiring public health attention, whose corporate instigation might markedly reduce the incidence, and perhaps halt or reverse the progression, of Alzheimer's disease.

\section{References}

[1] L. Bertram and R. E. Tanzi, "Alzheimer's disease: one disorder, too many genes?" Human Molecular Genetics, vol. 13, no. 1, pp. R135-R141, 2004.

[2] S. Cichon, N. Craddock, M. Daly et al., "Genomewide association studies: history, rationale, and prospects for psychiatric disorders," American Journal of Psychiatry, vol. 166, no. 5, pp. 540-556, 2009.

[3] V. Vacic, S. McCarthy, D. Malhotra et al., "Duplications of the neuropeptide receptor gene VIPR2 confer significant risk for schizophrenia," Nature, vol. 471, no. 7339, pp. 499-503, 2011.

[4] B. Bondy, "Genetics in psychiatry: are the promises met?" The World Journal of Biological Psychiatry, vol. 12, no. 2, pp. 8188, 2011.

[5] H. L. Li, S. S. Shi, Q. H. Guo et al., "PICALM and CR1 variants are not associated with sporadic Alzheimer's disease in Chinese patients," Journal of Alzheimer's Disease. http:// www.ncbi.nlm.nih.gov/pubmed/21358043. In press.

[6] G. Jun, A. C. Naj, G. W. Beecham et al., "Meta-analysis confirms CR1, CLU, and PICALM as Alzheimer disease risk loci and reveals interactions with APOE genotypes," Archives of Neurology, vol. 67, no. 12, pp. 1473-1484, 2010.

[7] P. J. Talmud, N. Yiannakouris, and S. E. Humphries, "Lipoprotein association studies: taking stock and moving forward," Current Opinion in Lipidology, vol. 22, no. 2, pp. 106-112, 2011.

[8] A. E. Handel, A. J. Williamson, G. Disanto, L. Handunnetthi, G. Giovannoni, and S. V. Ramagopalan, "An updated metaanalysis of risk of multiple sclerosis following infectious mononucleosis," PLoS ONE, vol. 5, no. 9, pp. 1-5, 2010.

[9] G. Ingram, J. J. Bugert, S. Loveless, and N. P. Robertson, "Anti-EBNA-1 IgG is not a reliable marker of multiple 
sclerosis clinical disease activity," European Journal of Neurology, vol. 17, no. 11, pp. 1386-1389, 2010.

[10] D. Franciotta, A. Bestetti, S. Sala et al., "Broad screening for human herpesviridae DNA in multiple sclerosis cerebrospinal fluid and serum," Acta Neurologica Belgica, vol. 109, no. 4, pp. 277-282, 2009.

[11] A. Papassotiropoulos, M. A. Wollmer, M. Tsolaki et al., "A cluster of cholesterol-related genes confers susceptibility for Alzheimer's disease," Journal of Clinical Psychiatry, vol. 66, no. 7, pp. 940-947, 2005.

[12] X. Wu, J. Gu, H. B. Grossman et al., "Bladder cancer predisposition: a multigenic approach to DNA-repair and cellcycle-control genes," American Journal of Human Genetics, vol. 78, no. 3, pp. 464-479, 2006.

[13] C. J. Carter, "Interactions between the products of the Herpes simplex genome and Alzheimer's disease susceptibility genes: relevance to pathological-signalling cascades," Neurochemistry International, vol. 52, no. 6, pp. 920-934, 2008.

[14] C. J. Carter, "Schizophrenia susceptibility genes directly implicated in the life cycles of pathogens: cytomegalovirus, influenza, herpes simplex, rubella, and Toxoplasma gondii," Schizophrenia bulletin, vol. 35, no. 6, pp. 1163-1182, 2009.

[15] H. Hemilä and J. Kaprio, "Vitamin E supplementation and pneumonia risk in males who initiated smoking at an early age: effect modification by body weight and dietary vitamin C," Nutrition Journal, vol. 7, no. 1, article 33, 2008.

[16] H. Hemilä and J. Kaprio, "Modification of the effect of vitamin E supplementation on the mortality of male smokers by age and dietary vitamin C," American Journal of Epidemiology, vol. 169, no. 8, pp. 946-953, 2009.

[17] H. Hemilä and J. Kaprio, "Vitamin E may affect the life expectancy of men, depending on dietary vitamin C intake and smoking," Age and Ageing, vol. 40, no. 2, pp. 215-220, 2011.

[18] I. L. Ferreira, R. Resende, E. Ferreiro, A. C. Rego, and C. F. Pereira, "Multiple defects in energy metabolism in Alzheimer's disease," Current Drug Targets, vol. 11, no. 10, pp. 1193-1206, 2010.

[19] M. Facheris, S. Beretta, and C. Ferrarese, "Peripheral markers of oxidative stress and excitotoxicity in neurodegenerative disorders: tools for diagnosis and therapy?" Journal of Alzheimer's Disease, vol. 6, no. 2, pp. 177-184, 2004.

[20] S. Goto, H. Bono, H. Ogata et al., "Organizing and computing metabolic pathway data in terms of binary relations," Pacific Symposium on Biocomputing, pp. 175-186, 1997.

[21] J. E. Larsen, O. Lund, and M. Nielsen, "Improved method for predicting linear B-cell epitopes," Immunome Research, vol. 2, article 2, 2006.

[22] S. F. Altschul, T. L. Madden, A. A. Schäffer et al., "Gapped BLAST and PSI-BLAST: a new generation of protein database search programs," Nucleic Acids Research, vol. 25, no. 17, pp. 3389-3402, 1997.

[23] M. Nielsen, C. Lundegaard, O. Lund, and C. Keşmir, "The role of the proteasome in generating cytotoxic T-cell epitopes: insights obtained from improved predictions of proteasomal cleavage," Immunogenetics, vol. 57, no. 1-2, pp. 33-41, 2005.

[24] A. Takaoka and S. Shinohara, "DNA sensors in innate immune system," Uirusu, vol. 58, no. 1, pp. 37-46, 2008.

[25] S. Chattopadhyay, J. T. Marques, M. Yamashita et al., "Viral apoptosis is induced by IRF-3-mediated activation of Bax," EMBO Journal, vol. 29, no. 10, pp. 1762-1773, 2010.
[26] L. S. Murillo, S. A. Morré, and A. S. Peña, "Toll-like receptors and NOD/CARD proteins: pattern recognition receptors are key elements in the regulation of immune response," Drugs of Today, vol. 39, no. 6, pp. 415-438, 2003.

[27] A. H. Oijen, M. L. Verhulst, H. M. Roelofs, W. H. Peters, W. A. de Boer, and J. B. Jansen, "Eradication of Helicobacter pylori restores glutathione S-transferase activity and glutathione levels in antral mucosa," Japanese Journal of Cancer Research, vol. 92, no. 12, pp. 1329-1334, 2001.

[28] A. Fraternale, M. F. Paoletti, A. Casabianca et al., "GSH and analogs in antiviral therapy," Molecular Aspects of Medicine, vol. 30, no. 1-2, pp. 99-110, 2009.

[29] Y. N. Zhang and K. M. Duan, "Glutathione exhibits antibacterial activity and increases tetracycline efficacy against Pseudomonas aeruginosa," Science in China Series C, vol. 52, no. 6, pp. 501-505, 2009.

[30] P. L. Páez, M. C. Becerra, and I. Albesa, "Effect of the association of reduced glutathione and ciprofloxacin on the antimicrobial activity in Staphylococcus aureus," FEMS Microbiology Letters, vol. 303, no. 1, pp. 101-105, 2010.

[31] M. Nakayama, J. Hisatsune, E. Yamasaki et al., "Helicobacter pylori VacA-induced inhibition of $\mathrm{GSK}_{3}$ through the $\mathrm{PI}_{3} \mathrm{~K} /$ Akt signaling pathway," Journal of Biological Chemistry, vol. 284, no. 3, pp. 1612-1619, 2009.

[32] R. Takenaka, K. Yokota, K. Ayada et al., "Helicobacter pylori heat-shock protein 60 induces inflammatory responses through the Toll-like receptor-triggered pathway in cultured human gastric epithelial cells," Microbiology, vol. 150, no. 12, pp. 3913-3922, 2004.

[33] C. J. Carter, "Alzheimer's disease plaques and tangles: cemeteries of a Pyrrhic victory of the immune defence network against herpes simplex infection at the expense of complement and inflammation-mediated neuronal destruction," Neurochemistry International, vol. 58, no. 3, pp. 301-320, 2011.

[34] D. R. Lees, "Genetic control of the melanic form insularia of the peppered moth biston betularia (L.)," Nature, vol. 220, no. 5173, pp. 1249-1250, 1968.

[35] J. C. Figueiredo, J. P. Lewinger, C. Song et al., "Genotypeenvironment interactions in MSS/MSI-low colorectal cancer: results from a genome-wide association study," Cancer Epidemiology, Biomarkers \& Prevention, vol. 20, p. 758, 2011.

[36] K. Oexle and T. Meitinger, "Sampling GWAS subjects from risk populations," Genetic Epidemiology, vol. 35, no. 3, pp. 148-153, 2011.

[37] H. Aschard, D. B. Hancock, S. J. London, and P. Kraft, "Genome-wide meta-analysis of joint tests for genetic and gene-environment interaction effects," Human Heredity, vol. 70, no. 4, pp. 292-300, 2010.

[38] R. F. Itzhaki, W. R. Lin, D. Shang, G. K. Wilcock, B. Faragher, and G. A. Jamieson, "Herpes simplex virus type 1 in brain and risk of Alzheimer's disease," Lancet, vol. 349, no. 9047, pp. 241-244, 1997.

[39] D. S. Goodman, "Plasma retinol-binding protein," Annals of the New York Academy of Sciences, vol. 348, pp. 378-390, 1980.

[40] Y. Liang, S. Lin, T. P. Beyer et al., "A liver X receptor and retinoid $\mathrm{X}$ receptor heterodimer mediates apolipoprotein $\mathrm{E}$ expression, secretion and cholesterol homeostasis in astrocytes," Journal of Neurochemistry, vol. 88, no. 3, pp. 623-634, 2004.

[41] R. Schindler and A. Klopp, "Transport of esterified retinol in fasting human blood," International Journal for Vitamin and Nutrition Research, vol. 56, no. 1, pp. 21-27, 1986. 
[42] H. M. Naylor and M. E. Newcomer, "The structure of human retinol-binding protein (RBP) with its carrier protein transthyretin reveals an interaction with the carboxy terminus of RBP," Biochemistry, vol. 38, no. 9, pp. 2647-2653, 1999.

[43] F. Boukhtouche, J. Mariani, and A. Tedgui, "The "CholesteROR" protective pathway in the vascular system," Arteriosclerosis, Thrombosis, and Vascular Biology, vol. 24, no. 4, pp. 637-643, 2004.

[44] M. M. Sousa, L. Berglund, and M. J. Saraiva, "Transthyretin in high density lipoproteins: association with apolipoprotein A-I," Journal of Lipid Research, vol. 41, no. 1, pp. 58-65, 2000.

[45] S. Smeland, S. O. Kolset, M. Lyon, K. R. Norum, and R. Blomhoff, "Binding of perlecan to transthyretin in vitro," Biochemical Journal, vol. 326, no. 3, pp. 829-836, 1997.

[46] T. C. Kiorpes, R. S. Anderson, and G. Wolf, "Effect of vitamin A deficiency on glycosylation of rat serum $\alpha$-macroglobulin," Journal of Nutrition, vol. 111, no. 12, pp. 2059-2068, 1981.

[47] R. P. Koldamova, I. M. Lefterov, M. D. Ikonomovic et al., "22R-hydroxycholesterol and 9-cis-retinoic acid induce ATPbinding cassette transporter A1 expression and cholesterol efflux in brain cells and decrease amyloid $\beta$ secretion," Journal of Biological Chemistry, vol. 278, no. 15, pp. 13244-13256, 2003.

[48] A. During and E. H. Harrison, "Mechanisms of provitamin A (carotenoid) and vitamin A (retinol) transport into and out of intestinal Caco-2 cells," Journal of Lipid Research, vol. 48, no. 10, pp. 2283-2294, 2007.

[49] E. Reboul, D. Trompier, M. Moussa et al., "ATP-binding cassette transporter A1 is significantly involved in the intestinal absorption of alpha- and gamma-tocopherol but not in that of retinyl palmitate in mice," The American Journal of Clinical Nutrition, vol. 89, no. 1, pp. 177-184, 2009.

[50] I. C. Gaemers, A. M. M. Van Pelt, A. P. N. Themmen, and D. G. De Rooij, "Isolation and characterization of all-transretinoic acid-responsive genes in the rat testis," Molecular Reproduction and Development, vol. 50, no. 1, pp. 1-6, 1998.

[51] C. R. Morales and M. D. Griswold, "Variations in the level of transferrin and SGP-2 mRNAs in Sertoli cells of vitamin A-deficient rats," Cell and Tissue Research, vol. 263, no. 1, pp. 125-130, 1991.

[52] S. K. Lee, H. S. Choi, M. R. Song, M. O. Lee, and J. W. Lee, "Estrogen receptor, a common interaction partner for a subset of nuclear receptors," Molecular Endocrinology, vol. 12, no. 8, pp. 1184-1192, 1998.

[53] M. A. Adly, "Expression of the carrier protein transthyretin and its receptor megalin in human skin: preliminary findings," British Journal of Dermatology, vol. 162, no. 1, pp. 213215,2010

[54] E. I. Christensen, J. O. Moskaug, H. Vorum et al., "Evidence for an essential role of megalin in transepithelial transport of retinol," Journal of the American Society of Nephrology, vol. 10, no. 4, pp. 685-695, 1999.

[55] W. Ambroziak, G. Izaguirre, and R. Pietruszko, "Metabolism of retinaldehyde and other aldehydes in soluble extracts of human liver and kidney," Journal of Biological Chemistry, vol. 274, no. 47, pp. 33366-33373, 1999.

[56] J. Pinaire, W. Y. Chou, M. Morton et al., "Identification of a retinoid receptor response element in the human aldehyde dehydrogenase-2 promoter," Alcoholism, vol. 27, no. 12, pp. 1860-1866, 2003.

[57] Y. Wang, N. Kumar, C. Crumbley, P. R. Griffin, and T. P. Burris, "A second class of nuclear receptors for oxysterols: regulation of RORalpha and RORgamma activity by $24 \mathrm{~S}$ hydroxycholesterol (cerebrosterol)," Biochimica et Biophysica Acta, vol. 1801, no. 8, pp. 917-923, 2010.

[58] H. Chen and M. R. Juchau, "Recombinant human glutathione S-transferases catalyse enzymic isomerization of 13cis-retinoic acid to all-trans-retinoic acid in vitro," Biochemical Journal, vol. 336, no. 1, pp. 223-226, 1998.

[59] D. E. Breithaupt, A. Bamedi, and U. Wirt, "Carotenol fatty acid esters: easy substrates for digestive enzymes?" Comparative Biochemistry and Physiology-B, vol. 132, no. 4, pp. 721$728,2002$.

[60] E. H. Harrison, "Lipases and carboxylesterases: possible roles in the hepatic utilization of vitamin A," Journal of Nutrition, vol. 130, no. 2, pp. 340S-344S, 2000.

[61] A. Woods, C. G. James, G. Wang, H. Dupuis, and F. Beier, "Control of chondrocyte gene expression by actin dynamics: a novel role of cholesterol/Ror- $\alpha$ signalling in endochondral bone growth," Journal of Cellular and Molecular Medicine, vol. 13, no. 9, pp. 3497-3516, 2009.

[62] X. Gong, S. W. Tsai, B. Yan, and L. P. Rubin, "Cooperation between MEF2 and PPAR $\gamma$ in human intestinal $\beta, \beta$-carotene 15, 15'-monooxygenase gene expression," BMC Molecular Biology, vol. 7, article 7, 2006.

[63] D. R. Johnson, J. M. Lovett, M. Hirsch, F. Xia, and J. D. Chen, "NuRD complex component Mi-2beta binds to and represses RORgamma-mediated transcriptional activation," Biochemical and Biophysical Research Communications, vol. 318, no. 3, pp. 714-718, 2004.

[64] X. H. Zhang, B. Zheng, M. Han, S. B. Miao, and J. K. Wen, "Synthetic retinoid Am80 inhibits interaction of KLF5 with RAR $\alpha$ through inducing KLF5 dephosphorylation mediated by the PI3K/Akt signaling in vascular smooth muscle cells," FEBS Letters, vol. 583, no. 8, pp. 1231-1236, 2009.

[65] P. McNamara, S. B. Seo, R. D. Rudic, A. Sehgal, D. Chakravarti, and G. A. FitzGerald, "Regulation of CLOCK and MOP4 by nuclear hormone receptors in the vasculature: a humoral mechanism to reset a peripheral clock," Cell, vol. 105, no. 7, pp. 877-889, 2001.

[66] C. Crumbley, Y. Wang, D. J. Kojetin, and T. P. Burris, "Characterization of the core mammalian clock component, NPAS2, as a REV-ERBalpha/RORalpha target gene," The Journal of Biological Chemistry, vol. 285, no. 46, pp. 3538635392, 2010.

[67] R. Pavri, B. Lewis, T. K. Kim et al., "PARP-1 determines specificity in a retinoid signaling pathway via direct modulation of mediator," Molecular Cell, vol. 18, no. 1, pp. 83-96, 2005.

[68] M. Gianni', A. Boldetti, V. Guarnaccia et al., "Inhibition of the peptidyl-prolyl-isomerase Pin1 enhances the responses of acute myeloid leukemia cells to retinoic acid via stabilization of RAR $\alpha$ and PML-RAR $\alpha$," Cancer Research, vol. 69, no. 3, pp. 1016-1026, 2009.

[69] T. Kakizawa, T. Miyamoto, K. Ichikawa et al., "Functional interaction between Oct-1 and retinoid X receptor," Journal of Biological Chemistry, vol. 274, no. 27, pp. 19103-19108, 1999.

[70] A. Gorla-Bajszczak, C. Juge-Aubry, A. Pernin, A. G. Burger, and C. A. Meier, "Conserved amino acids in the ligandbinding and tau(i) domains of the peroxisome proliferatoractivated receptor alpha are necessary for heterodimerization with RXR," Molecular and Cellular Endocrinology, vol. 147, no. 1-2, pp. 37-47, 1999.

[71] T. Wang, J. Xu, X. Yu, R. Yang, and Z. C. Han, "Peroxisome proliferator-activated receptor gamma in malignant 
diseases," Critical Reviews in Oncology / Hematology, vol. 58, no. 1, pp. 1-14, 2006.

[72] G. E. O. Muscat, L. Mynett-Johnson, D. Dowhan, M. Downes, and R. Griggs, "Activation of myoD gene transcription by 3,5,3'-triiodo-L-thyronine: a direct role for the thyroid hormone and retinoid X receptors," Nucleic Acids Research, vol. 22, no. 4, pp. 583-591, 1994.

[73] D. Zhu, C. Wang, B. Liu, Y. Wu, L. Zhong, and C. Wang, "Interaction between nuclear localization signal-retinoic acid receptor alpha and Ubiquilin 1," Journal of Central South University, vol. 35, no. 7, pp. 649-654, 2010.

[74] N. J. Koszewski, J. Herberth, and H. H. Malluche, "Retinoic acid receptor gamma 2 interactions with vitamin D response elements," Journal of Steroid Biochemistry and Molecular Biology, vol. 120, no. 4-5, pp. 200-207, 2010.

[75] Y. Gao and S. W. Pimplikar, "The $\gamma$-secretase-cleaved Cterminal fragment of amyloid precursor protein mediates signaling to the nucleus," Proceedings of the National Academy of Sciences of the United States of America, vol. 98, no. 26, pp. 14979-14984, 2001.

[76] A. Koryakina, J. Aeberhard, S. Kiefer, M. Hamburger, and P. Küenzi, "Regulation of secretases by all-trans-retinoic acid," FEBS Journal, vol. 276, no. 9, pp. 2645-2655, 2009.

[77] S. N. Sarkar and H. K. Das, "Regulatory roles of presenilin1 and nicastrin in neuronal differentiation during in vitro neurogenesis," Journal of Neurochemistry, vol. 87, no. 2, pp. 333-343, 2003.

[78] F. Flood, E. Sundström, E. B. Samuelsson et al., "Presenilin expression during induced differentiation of the human neuroblastoma SH-SY5Y cell line," Neurochemistry International, vol. 44, no. 7, pp. 487-496, 2004.

[79] K. Uemura, N. Kitagawa, R. Kohno et al., "Presenilin 1 mediates retinoic acid-induced differentiation of SH-SY5Y cells through facilitation of Wnt signaling," Journal of Neuroscience Research, vol. 73, no. 2, pp. 166-175, 2003.

[80] R. Kitching, S. Qi, V. Li, A. Raouf, C. P. H. Vary, and A. Seth, "Coordinate gene expression patterns during osteoblast maturation and retinoic acid treatment of MC3T3-E1 cells," Journal of Bone and Mineral Metabolism, vol. 20, no. 5, pp. 269-280, 2002.

[81] H. S. Kuo, F. N. Hsu, M. C. Chiang et al., "The role of Cdk5 in retinoic acid-induced apoptosis of cervical cancer cell line," Chinese Journal of Physiology, vol. 52, no. 1, pp. 23-30, 2009.

[82] A. Jämsä, K. Hasslund, R. F. Cowburn, A. Bäckström, and M. Vasänge, "The retinoic acid and brain-derived neurotrophic factor differentiated SH-SY5Y cell line as a model for Alzheimer's disease-like tau phosphorylation," Biochemical and Biophysical Research Communications, vol. 319, no. 3, pp. 993-1000, 2004.

[83] M. C. Monteiro, B. Wdziekonski, P. Villageois et al., "Commitment of mouse embryonic stem cells to the adipocyte lineage requires retinoic acid receptor $\beta$ and active GSK3," Stem Cells and Development, vol. 18, no. 3, pp. 457-463, 2009.

[84] N. Haque, T. Tanaka, K. Iqbal, and I. Grundke-Iqbal, "Regulation of expression, phosphorylation and biological activity of tau during differentiation in SY5Y cells," Brain Research, vol. 838, no. 1-2, pp. 69-77, 1999.

[85] M. K. Oeff, H. Seltmann, N. Hiroi et al., "Differential regulation of toll-like receptor and CD14 pathways by retinoids and corticosteroids in human sebocytes," Dermatology, vol. 213, no. 3, p. 266, 2006.

[86] C. M. Bliss Jr., D. T. Golenbock, S. Keates, J. K. Linevsky, and C. P. Kelly, "Helicobacter pylori lipopolysaccharide binds to CD14 and stimulates release of interleukin-8, epithelial neutrophil-activating peptide 78, and monocyte chemotactic protein 1 by human monocytes," Infection and Immunity, vol. 66, no. 11, pp. 5357-5363, 1998.

[87] Y. Ma, Q. Chen, and A. C. Ross, "Retinoic acid and polyriboinosinic: polyribocytidylic acid stimulate robust antitetanus antibody production while differentially regulating type 1/type 2 cytokines and lymphocyte populations," Journal of Immunology, vol. 174, no. 12, pp. 7961-7969, 2005.

[88] S. U. Gorr and M. Abdolhosseini, "Antimicrobial peptides and periodontal disease," Journal of Clinical Periodontology, vol. 38, supplement 11, pp. 126-141, 2011.

[89] A. Yen, D. M. Lin, T. J. Lamkin, and S. Varvayanis, "Retinoic acid, bromodeoxyuridine, and the $\Delta 205$ mutant polyoma virus middle $\mathrm{T}$ antigen regulate expression levels of a common ensemble of proteins associated with early stages of inducing HL-60 leukemic cell differentiation," In Vitro Cellular and Developmental Biology, vol. 40, no. 7, pp. 216241, 2004.

[90] P. Desreumaux, L. Dubuquoy, S. Nutten et al., "Attenuation of colon inflammation through activators of the retinoid $\mathrm{X}$ receptor (RXR)/peroxisome proliferator-activated receptor gamma (PPARgamma) heterodimer. A basis for new therapeutic strategies," The Journal of Experimental Medicine, vol. 193, no. 7, pp. 827-838, 2001.

[91] T. Saitoh, A. Tun-Kyi, A. Ryo et al., "Negative regulation of interferon-regulatory factor 3-dependent innate antiviral response by the prolyl isomerase Pin1," Nature Immunology, vol. 7, no. 6, pp. 598-605, 2006.

[92] R. Hertz, M. Seckbach, M. M. Zakin, and J. Bar-Tana, “Transcriptional suppression of the transferrin gene by hypolipidemic peroxisome proliferators," Journal of Biological Chemistry, vol. 271, no. 1, pp. 218-224, 1996.

[93] B. Gu, J. Miao, Y. Fa, J. Lu, and S. Zou, "Retinoic acid attenuates lipopolysaccharide-induced inflammatory responses by suppressing TLR4/NF- $\kappa$ B expression in rat mammary tissue," International Immunopharmacology, vol. 10, no. 7, pp. 799$805,2010$.

[94] S. Murthy, E. Born, S. N. Mathur, and F. J. Field, "LXR/RXR activation enhances basolateral efflux of cholesterol in CaCo2 cells," Journal of Lipid Research, vol. 43, no. 7, pp. 10541064, 2002.

[95] U. Lind, T. Nilsson, J. McPheat et al., "Identification of the human ApoAV gene as a novel RORalpha target gene," Biochemical and Biophysical Research Communications, vol. 330, no. 1, pp. 233-241, 2005.

[96] R. Moreno, F. Perez-Jimenez, C. Marin et al., "A single nucleotide polymorphism of the apolipoprotein A-V gene $1131 \mathrm{~T}$ > C modulates postprandial lipoprotein metabolism," Atherosclerosis, vol. 189, no. 1, pp. 163-168, 2006.

[97] D. Kardassis, A. Roussou, P. Papakosta, K. Boulias, I. Talianidis, and V. I. Zannis, "Synergism between nuclear receptors bound to specific hormone response elements of the hepatic control region-1 and the proximal apolipoprotein C-II promoter mediate apolipoprotein C-II gene regulation by bile acids and retinoids," Biochemical Journal, vol. 372, no. 2, pp. 291-304, 2003.

[98] P. A. Mak, B. A. Laffitte, C. Desrumaux et al., "Regulated expression of the apolipoprotein E/C-I/C-IV/C-II gene cluster in murine and human macrophages: a critical role for nuclear liver X receptors $\alpha$ and $\beta$," Journal of Biological Chemistry, vol. 277, no. 35, pp. 31900-31908, 2002.

[99] Y. S. Lopez-Boado, M. Klaus, M. I. Dawson, and C. LopezOtin, "Retinoic acid-induced expression of apolipoprotein D and concomitant growth arrest in human breast cancer cells 
are mediated through a retinoic acid receptor RARalphadependent signaling pathway," The Journal of Biological Chemistry, vol. 271, no. 50, pp. 32105-32111, 1996.

[100] G. D. Norata, M. Ongari, P. Uboldi, F. Pellegatta, and A. L. Catapano, "Liver X receptor and retinoic X receptor agonists modulate the expression of genes involved in lipid metabolism in human endothelial cells," International Journal of Molecular Medicine, vol. 16, no. 4, pp. 717-722, 2005.

[101] J. Fukuchi, C. Song, A. L. Ko, and S. Liao, "Transcriptional regulation of farnesyl pyrophosphate synthase by liver $\mathrm{X}$ receptors," Steroids, vol. 68, no. 7-8, pp. 685-691, 2003.

[102] S. Georgala, K. H. Schulpis, I. Potouridou, and H. Papadogeorgaki, "Effects of isotretinoin therapy on lipoprotein (a) serum levels," International Journal of Dermatology, vol. 36, no. 11, pp. 863-864, 1997.

[103] R. Verani, I. Cappuccio, P. Spinsanti et al., "Expression of the Wnt inhibitor Dickkopf-1 is required for the induction of neural markers in mouse embryonic stem cells differentiating in response to retinoic acid," Journal of Neurochemistry, vol. 100, no. 1, pp. 242-250, 2007.

[104] A. M. Padovani, M. F. Molina, and K. K. Mann, "Inhibition of liver X receptor/retinoid X receptor-mediated transcription contributes to the proatherogenic effects of arsenic in macrophages in vitro," Arteriosclerosis, Thrombosis, and Vascular Biology, vol. 30, no. 6, pp. 1228-1236, 2010.

[105] P. Yang, Z. Liu, H. Wang et al., "Enhanced activity of very low density lipoprotein receptor II promotes SGC7901 cell proliferation and migration," Life Sciences, vol. 84, no. 13-14, pp. 402-408, 2009.

[106] M. R. de Oliveira, M. W. S. Oliveira, G. A. Behr, M. A. B. Pasquali, and J. C. F. Moreira, "Increased receptor for advanced glycation endproducts immunocontent in the cerebral cortex of vitamin a-treated rats," Neurochemical Research, vol. 34, no. 8, pp. 1410-1416, 2009.

[107] D. P. Gelain, M. A. B. Pasquali, F. F. Caregnato, A. ZanottoFilho, and J. C. Moreira, "Retinol up-regulates the receptor for advanced glycation endproducts (RAGE) by increasing intracellular reactive species," Toxicology in Vitro, vol. 22, no. 5, pp. 1123-1127, 2008.

[108] R. M. Moretti, M. M. Montagnani, A. Sala, M. Motta, and P. Limonta, "Activation of the orphan nuclear receptor ROR $\alpha$ counteracts the proliferative effect of fatty acids on prostate cancer cells: crucial role of 5-lipoxygenase," International Journal of Cancer, vol. 112, no. 1, pp. 87-93, 2004.

[109] S. van Neerven, T. Regen, D. Wolf et al., "Inflammatory chemokine release of astrocytes in vitro is reduced by alltrans retinoic acid," Journal of Neurochemistry, vol. 114, no. 5, pp. 1511-1526, 2010.

[110] J. Ko, C. Y. Yun, J. S. Lee, J. H. Kim, and I. S. Kim, “p38 MAPK and ERK activation by 9-cis-retinoic acid induces chemokine receptors CCR1 and CCR2 expression in human monocytic THP-1 cells," Experimental and Molecular Medicine, vol. 39, no. 2, pp. 129-138, 2007.

[111] X. Wang, C. Allen, and M. Ballow, "Retinoic acid enhances the production of IL- 10 while reducing the synthesis of IL-12 and TNF- $\alpha$ from LPS-stimulated monocytes/macrophages," Journal of Clinical Immunology, vol. 27, no. 2, pp. 193-200, 2007.

[112] H. Sallmon, V. Hoene, S. C. Weber, and C. Dame, "Differentiation of human SH-SY5Y neuroblastoma cells by all-trans retinoic acid activates the interleukin-18 system," Journal of Interferon and Cytokine Research, vol. 30, no. 2, pp. 55-58, 2010 .
[113] M. Napolitano, D. Bellavia, M. Maroder et al., "Modulation of cytokine gene expression by thymic lympho-stromal cell to cell interaction: effect of retinoic acid," Thymus, vol. 24, no. 4, pp. 247-258, 1997.

[114] S. van Neerven, J. Mey, E. A. Joosten et al., "Systemic but not local administration of retinoic acid reduces early transcript levels of pro-inflammatory cytokines after experimental spinal cord injury," Neuroscience Letters, vol. 485, no. 1, pp. 21-25, 2010.

[115] D. Wågsäter, K. Jatta, P. Ocaya, J. Dimberg, and A. Sirsjö, "Expression of IL-1 $\beta$, IL-1 receptor type I and IL-1 receptor antagonist in human aortic smooth muscle cells: effects of all-trans-retinoic acid," Journal of Vascular Research, vol. 43, no. 4, pp. 377-382, 2006.

[116] B. Gu, Y. Zhu, W. Zhu, J. Miao, Y. Deng, and S. Zou, "Retinoid protects rats against neutrophil-induced oxidative stress in acute experimental mastitis," International Immunopharmacology, vol. 9, no. 2, pp. 223-229, 2009.

[117] S. Hashimoto, S. Hayashi, S. Yoshida et al., "Retinoic acid differentially regulates interleukin- $1 \beta$ and interleukin-1 receptor antagonist production by human alveolar macrophages," Leukemia Research, vol. 22, no. 11, pp. 1057-1061, 1998.

[118] S. Song, B. Guan, T. Men, A. Hoque, R. Lotan, and X. C. $\mathrm{Xu}$, "Antitumor effect of retinoic acid receptor- $\beta$ associated with suppression of cyclooxygenase-2," Cancer Prevention Research, vol. 2, no. 3, pp. 274-280, 2009.

[119] S. J. Lee, E. K. Yang, and S. G. Kim, "Peroxisome proliferatoractivated receptor-gamma and retinoic acid X receptor alpha represses the TGFbetal gene via PTEN-mediated p70 ribosomal S6 kinase-1 inhibition: role for Zf9 dephosphorylation," Molecular Pharmacology, vol. 70, no. 1, pp. 415-425, 2006.

[120] J. Wang, S. Wu, X. Jin et al., "Retinoic acid-inducible gene-i mediates late phase induction of TNF- $\alpha$ by lipopolysaccharide," Journal of Immunology, vol. 180, no. 12, pp. 8011-8019, 2008.

[121] F. Fidanza, P. Sarchielli, P. Jordan, E. Lüdin, W. Schalch, and B. J. Weimann, "Vitamin nutritional status and immunocompetence of elderly in Perugia (Italy): an epidemiological approach," International Journal for Vitamin and Nutrition Research, vol. 61, no. 3, pp. 224-231, 1991.

[122] P. Munoz-Canoves, D. P. Vik, and B. F. Tack, "Mapping of a retinoic acid-responsive element in the promoter region of the complement factor $\mathrm{H}$ gene," Journal of Biological Chemistry, vol. 265, no. 33, pp. 20065-20068, 1990.

[123] R. M. Greer, H. M. Buntain, P. J. Lewindon et al., "Vitamin A levels in patients with $\mathrm{CF}$ are influenced by the inflammatory response," Journal of Cystic Fibrosis, vol. 3, no. 3, pp. 143-149, 2004.

[124] S. Thompson, P. L. Stern, M. Webb et al., "Cloned human teratoma cells differentiate into neuron-like cells and other cell types in retinoic acid," Journal of Cell Science, vol. 72, pp. 37-64, 1984.

[125] F. Lancillotti, V. Giandomenico, E. Affabris, G. Fiorucci, G. Romeo, and G. B. Rossi, "Interferon $\alpha-2 \mathrm{~b}$ and retinoic acid combined treatment affects proliferation and gene expression of human cervical carcinoma cells," Cancer Research, vol. 55, no. 14, pp. 3158-3164, 1995.

[126] M. Jinushi, T. Takehara, T. Tatsumi et al., "Expression and role of MICA and MICB in human hepatocellular carcinomas and their regulation by retinoic acid," International Journal of Cancer, vol. 104, no. 3, pp. 354-361, 2003.

[127] E. Czeczuga-Semeniuk, K. Jarzabek, D. Lemancewicz, and S. Wolczynski, “The vitamin A family can significantly decrease 
the expression of ERbeta of ERs positive breast cancer cells in the presence or absence of ER ligands and paclitaxel," Gynecological Endocrinology, vol. 25, no. 5, pp. 287-293, 2009.

[128] H. Odawara, T. Iwasaki, J. Horiguchi et al., "Activation of aromatase expression by retinoic acid receptor-related orphan receptor (ROR) $\alpha$ in breast cancer cells: identification of a novel ROR response element," Journal of Biological Chemistry, vol. 284, no. 26, pp. 17711-17719, 2009.

[129] S. Kheirvari, K. Uezu, S. Yamamoto, and Y. Nakaya, "Highdose dietary supplementation of vitamin A induces brainderived neurotrophic factor and nerve growth factor production in mice with simultaneous deficiency of vitamin A and zinc," Nutritional Neuroscience, vol. 11, no. 5, pp. 228-234, 2008.

[130] H. Katsuki, E. Kurimoto, S. Takemori et al., "Retinoic acid receptor stimulation protects midbrain dopaminergic neurons from inflammatory degeneration via BDNF-mediated signaling," Journal of Neurochemistry, vol. 110, no. 2, pp. 707718, 2009.

[131] C. C. Chen, L. W. Hsu, L. T. Huang, and T. L. Huang, "Chronic administration of cyclosporine a changes expression of BDNF and TrkB in rat hippocampus and midbrain," Neurochemical Research, vol. 35, no. 7, pp. 1098-1104, 2010.

[132] N. Dey, P. K. De, M. Wang et al., "CSK controls Retinoic Acid Receptor (RAR) signaling: a RAR-c-SRC signaling axis is required for neuritogenic differentiation," Molecular and Cellular Biology, vol. 27, no. 11, pp. 4179-4197, 2007.

[133] X. Wan, P. Nass, M. D. Duncan, and J. W. Harmon, "Acidic fibroblast growth factor overexpression partially protects 3T3 fibroblasts from apoptosis induced by synthetic retinoid CD437," Journal of Molecular Medicine, vol. 79, no. 2, pp. 143-148, 2001.

[134] Y. Mao and A. W. M. Lee, "A novel role for Gab2 in bFGFmediated cell survival during retinoic acid-induced neuronal differentiation," Journal of Cell Biology, vol. 170, no. 2, pp. 305-316, 2005.

[135] M. Jaradat, C. Stapleton, S. L. Tilley et al., "Modulatory role for retinoid-related orphan receptor alpha in allergeninduced lung inflammation," American Journal of Respiratory and Critical Care Medicine, vol. 174, no. 12, pp. 1299-1309, 2006.

[136] E. Bonnet, K. Touyarot, S. Alfos, V. Pallet, P. Higueret, and D. N. Abrous, "Retinoic acid restores adult hippocampal neurogenesis and reverses spatial memory deficit in vitamin A deprived rats," PLoS ONE, vol. 3, no. 10, Article ID e3487, 2008.

[137] N. Sidell, Y. Feng, L. Hao et al., "Retinoic acid is a cofactor for translational regulation of vascular endothelial growth factor in human endometrial stromal cells," Molecular Endocrinology, vol. 24, no. 1, pp. 148-160, 2010.

[138] M. Zhang, K. Huang, Z. Zhang et al., "Proteome alterations of cortex and hippocampus tissues in mice subjected to vitamin A depletion," Journal of Nutritional Biochemistry. http://www.ncbi.nlm.nih.gov/pubmed/21190828. In press.

[139] J. Zimny, "Mechanisms that protect against homocysteine toxicity," Postepy biochemii, vol. 54, no. 1, pp. 91-98, 2008.

[140] Y. Y. Xu, D. Y. Guan, M. Yang, H. Wang, and Z. H. Shen, "All-trans-retinoic acid intensifies endoplasmic reticulum stress in $\mathrm{N}$-acetylglucosaminyltransferase $\mathrm{V}$ repressed human hepatocarcinoma cells by perturbing homocysteine metabolism," Journal of Cellular Biochemistry, vol. 109, no. 3, pp. 468-477, 2010.
[141] I. Pascual, I. M. Larrayoz, and I. R. Rodriguez, "Retinoic acid regulates the human methionine sulfoxide reductase A (MSRA) gene via two distinct promoters," Genomics, vol. 93, no. 1, pp. 62-71, 2009.

[142] D. Fell and R. D. Steele, "Modification of hepatic folate metabolism in rats fed excess retinol," Life Sciences, vol. 38, no. 21, pp. 1959-1965, 1986.

[143] A. Bayrak, T. Bayrak, E. Demirpence, and K. Kilinc, "Differential hydrolysis of homocysteine thiolactone by purified human serum ${ }^{192} \mathrm{Q}$ and ${ }^{192} \mathrm{R}$ PON1 isoenzymes," Journal of Chromatography B, vol. 879, no. 1, pp. 49-55, 2011.

[144] L. V. Gatica, V. A. Vega, F. Zirulnik, L. B. Oliveros, and M. S. Gimenez, "Alterations in the lipid metabolism of rat aorta: effects of vitamin A deficiency," Journal of Vascular Research, vol. 43, no. 6, pp. 602-610, 2006.

[145] Y. W. Lin, L. M. Lien, T. S. Yeh, H. M. Wu, Y. L. Liu, and R. H. Hsieh, "9-cis retinoic acid induces retinoid $\mathrm{X}$ receptor localized to the mitochondria for mediation of mitochondrial transcription," Biochemical and Biophysical Research Communications, vol. 377, no. 2, pp. 351-354, 2008.

[146] J. Amengual, J. Ribot, M. L. Bonet, and A. Palou, "Retinoic acid treatment increases lipid oxidation capacity in skeletal muscle of mice," Obesity, vol. 16, no. 3, pp. 585-591, 2008.

[147] B. Trojanowicz, C. Sekulla, K. Lorenz et al., "Proteomic approach reveals novel targets for retinoic acid-mediated therapy of thyroid carcinoma," Molecular and Cellular Endocrinology, vol. 325, no. 1-2, pp. 110-117, 2010.

[148] S. Giera, A. Braeuning, C. Kohle et al., "Wnt/beta-catenin signaling activates and determines hepatic zonal expression of glutathione S-transferases in mouse liver," The Journal of Toxicological Sciences, vol. 115, no. 1, pp. 22-33, 2010.

[149] C. Jimenez, I. Leets, R. Puche et al., "A single dose of vitamin A improves haemoglobin concentration, retinol status and phagocytic function of neutrophils in preschool children," British Journal of Nutrition, vol. 103, no. 6, pp. 798-802, 2010.

[150] S. Y. Lee, S. Liu, R. M. Mitchell et al., "HFE polymorphisms influence the response to chemotherapeutic agents via induction of p16INK4A," International Journal of Cancer. http://www.ncbi.nlm.nih.gov/pubmed?term=21190189. In press.

[151] W. Samuel, R. K. Kutty, S. Nagineni, C. Vijayasarathy, R. A. S. Chandraratna, and B. Wiggert, "N-(4-hydroxyphenyl)retinamide induces apoptosis in human retinal pigment epithelial cells: retinoic acid receptors regulate apoptosis, reactive oxygen species generation, and the expression of heme oxygenase-1 and Gadd153," Journal of Cellular Physiology, vol. 209, no. 3, pp. 854-865, 2006.

[152] K. I. Mills, L. J. Woodgate, A. F. Gilkes et al., "Inhibition of mitochondrial function in HL60 cells is associated with an increased apoptosis and expression of CD14," Biochemical and Biophysical Research Communications, vol. 263, no. 2, pp. 294-300, 1999.

[153] K. P. Tan, K. Kosuge, M. Yang, and S. Ito, "NRF2 as a determinant of cellular resistance in retinoic acid cytotoxicity," Free Radical Biology and Medicine, vol. 45, no. 12, pp. 1663-1673, 2008.

[154] F. Zhao, T. Wu, A. Lau et al., "Nrf2 promotes neuronal cell differentiation," Free Radical Biology and Medicine, vol. 47, no. 6, pp. 867-879, 2009.

[155] K. K. Kiningham, Z. A. Cardozo, C. Cook et al., "All-transretinoic acid induces manganese superoxide dismutase in human neuroblastoma through NF- $\kappa \mathrm{B}$," Free Radical Biology and Medicine, vol. 44, no. 8, pp. 1610-1616, 2008. 
[156] T. Cadoudal, M. Glorian, A. Massias, F. Fouque, C. Forest, and C. Benelli, "Retinoids upregulate phosphoenolpyruvate carboxykinase and glyceroneogenesis in human and rodent adipocytes," Journal of Nutrition, vol. 138, no. 6, pp. 1004 1009, 2008.

[157] H. B. Everts, D. O. Claassen, C. L. Hermoyian, and C. D. Berdanier, "Nutrient-gene interactions: dietary vitamin A and mitochondrial gene expression," IUBMB Life, vol. 53, no. 6, pp. 295-301, 2002.

[158] Y. Y. Xu, Y. Lu, K. Y. Fan, and Z. H. Shen, "Apoptosis induced by all-trans retinoic acid in $\mathrm{N}$ - acetylglucosaminyltransferase $\mathrm{V}$ repressed human hepatocarcinoma cells is mediated through endoplasmic reticulum stress," Journal of Cellular Biochemistry, vol. 100, no. 3, pp. 773-782, 2007.

[159] S. W. Bahouth, M. J. Beauchamp, and E. A. Park, "Identification of a retinoic acid response domain involved in the activation of the $\beta$-adrenergic receptor gene by retinoic acid in F9 teratocarcinoma cells," Biochemical Pharmacology, vol. 55, no. 2, pp. 215-225, 1998.

[160] L. Liu, F. Derguini, and L. J. Gudas, "Metabolism and regulation of gene expression by 4-oxoretinol versus all-trans retinoic acid in normal human mammary epithelial cells," Journal of Cellular Physiology, vol. 220, no. 3, pp. 771-779, 2009.

[161] S. M. Salih, M. Jamaluddin, S. A. Salama, A. A. Fadl, M. Nagamani, and A. Al-Hendy, "Regulation of catechol Omethyltransferase expression in granulosa cells: a potential role for follicular arrest in polycystic ovary syndrome," Fertility and Sterility, vol. 89, no. 5, pp. 1414-1421, 2008.

[162] S. Sharma and M. F. Notter, "Characterization of neurotransmitter phenotype during neuronal differentiation of embryonal carcinoma cells," Developmental Biology, vol. 125, no. 2, pp. 246-254, 1988.

[163] X. Castell, M. F. Diebler, M. Tomasi et al., "More than one way to toy with ChAT and VAChT," Journal of Physiology Paris, vol. 96, no. 1-2, pp. 61-72, 2002.

[164] M. Nilbratt, L. Friberg, M. Mousavi, A. Marutle, and A. Nordberg, "Retinoic acid and nerve growth factor induce differential regulation of nicotinic acetylcholine receptor subunit expression in SN56 cells," Journal of Neuroscience Research, vol. 85, no. 3, pp. 504-514, 2007.

[165] C. H. P. Ong, Z. He, L. Kriazhev, X. Shan, R. G. E. Palfree, and A. Bateman, "Regulation of progranulin expression in myeloid cells," American Journal of Physiology, vol. 291, no. 6, pp. R1602-R1612, 2006.

[166] A. Oikarinen, T. Vuorio, J. Makela, and E. Vuorio, "13cis retinoic acid and dexamethasone modulate the gene expression of epidermal growth factor receptor and fibroblast proteoglycan 40 core protein in human skin fibroblasts," Acta Dermato-Venereologica, vol. 69, no. 6, pp. 466-469, 1989.

[167] C. Chang, X. H. Chen, P. Y. Kong et al., "In vitro effect of all-trans retinoic acid on cell adhesion molecule expression and adhesion capacity of bone marrow stromal cells in patients received peripheral blood stem cell transplantation," Journal of experimental hematology / Chinese Association of Pathophysiology, vol. 14, no. 4, pp. 768-772, 2006.

[168] M. R. Davies, L. R. Ribeiro, M. Downey-Jones, M. R. C. Needham, C. Oakley, and J. Wardale, "Ligands for retinoic acid receptors are elevated in osteoarthritis and may contribute to pathologic processes in the osteoarthritic joint," Arthritis and Rheumatism, vol. 60, no. 6, pp. 1722-1732, 2009.
[169] S. Hatakeyama, S. Hayashi, Y. Yoshida et al., "Retinoic acid disintegrated desmosomes and hemidesmosomes in stratified oral keratinocytes," Journal of Oral Pathology and Medicine, vol. 33, no. 10, pp. 622-628, 2004.

[170] K. Okumura, Y. Hosoe, and N. Nakajima, "c-Jun and Sp1 family are critical for retinoic acid induction of the lamin A/C retinoic acid-responsive element," Biochemical and Biophysical Research Communications, vol. 320, no. 2, pp. 487-492, 2004.

[171] Y. Fang, X. Zhou, M. Lin et al., "The ubiquitin-proteasome pathway plays essential roles in ATRA-induced leukemia cells G0/G1 phase arrest and transition into granulocytic differentiation," Cancer Biology and Therapy, vol. 10, no. 11, pp. 1157-1167, 2010.

[172] J. Liu, A. P. Li, C. P. Li, Z. D. Zhang, and J. W. Zhou, "The role of reactive oxygen species in $\mathrm{N}$-[4-hydroxyphenyl] retinamide induced apoptosis in bladder cancer cell lineT24," Chinese journal of industrial hygiene and occupational diseases, vol. 23, no. 3, pp. 191-194, 2005.

[173] L. T. Lee, K. C. Tan-Un, and B. K. Chow, "Retinoic acidinduced human secretin gene expression in neuronal cells is mediated by cyclin-dependent kinase 1," Annals of the New York Academy of Sciences, vol. 1070, pp. 393-398, 2006.

[174] K. A. Latif, I. Amla, and P. B. Rao, "Urinary excretion of arylsulfatases in malnourished/vitamin A deficient children," Clinica Chimica Acta, vol. 96, no. 1-2, pp. 131-138, 1979.

[175] K. Kasashima, K. Terashima, K. Yamamoto, E. Sakashita, and H. Sakamoto, "Cytoplasmic localization is required for the mammalian ELAV-like protein $\mathrm{HuD}$ to induce neuronal differentiation," Genes to Cells, vol. 4, no. 11, pp. 667-683, 1999.

[176] A. Kihara, M. Ikeda, Y. Kariya, E. Y. Lee, Y. M. Lee, and Y. Igarashi, "Sphingosine-1-phosphate lyase is involved in the differentiation of F9 embryonal carcinoma cells to primitive endoderm," Journal of Biological Chemistry, vol. 278, no. 16, pp. 14578-14585, 2003.

[177] J. A. Dembowski and P. J. Grabowski, "The CUGBP2 splicing factor regulates an ensemble of branchpoints from perimeter binding sites with implications for autoregulation," PLoS Genetics, vol. 5, no. 8, Article ID e1000595, 2009.

[178] T. M. Chlon, D. A. Taffany, J. Welsh, and M. J. Rowling, "Retinoids modulate expression of the endocytic partners megalin, cubilin, and disabled-2 and uptake of vitamin D-binding protein in human mammary cells," Journal of Nutrition, vol. 138, no. 7, pp. 1323-1328, 2008.

[179] B. A. Kudriashov, A. M. Ul'ianov, G. G. Bazaz'ian, and N. P. Sytina, "Factor XIII activity in the presence of suppression of the function of the anticoagulant system and its restoration in animals on an atherogenic ration," Voprosy pitaniia, no. 5, pp. 54-57, 1976.

[180] C. Puppin, F. Puglisi, L. Pellizzari et al., "HEX expression and localization in normal mammary gland and breast carcinoma," BMC Cancer, vol. 6, article 192, 2006.

[181] D. C. Knutson and M. Clagett-Dame, "atRA Regulation of NEDD9, a gene involved in neurite outgrowth and cell adhesion," Archives of Biochemistry and Biophysics, vol. 477, no. 1, pp. 163-174, 2008.

[182] Y. Chen, R. P. Sharma, R. H. Costa, E. Costa, and D. R. Grayson, "On the epigenetic regulation of the human reelin promoter," Nucleic Acids Research, vol. 30, no. 13, pp. 29302939, 2002.

[183] L. Russell, H. Naora, and H. Naora, "Down-regulated RPS3a/ $\mathrm{nbl}$ expression during retinoid-induced differentiation of 
HL-60 cells: a close association with diminished susceptibility to actinomycin D-stimulated apoptosis," Cell Structure and Function, vol. 25, no. 2, pp. 103-113, 2000.

[184] J. Zhang, L. P. Song, Y. Huang, Q. Zhao, K. W. Zhao, and G. Q. Chen, "Accumulation of hypoxia-inducible factor- $1 \alpha$ protein and its role in the differentiation of myeloid leukemic cells induced by all-trans retinoic acid," Haematologica, vol. 93, no. 10, pp. 1480-1487, 2008.

[185] M. Takehashi, S. Tanaka, T. Stedeford et al., "Expression of septin 3 isoforms in human brain," Gene Expression, vol. 11, no. 5-6, pp. 271-278, 2004.

[186] K. Ono and M. Yamada, "Vitamin A potently destabilizes preformed alpha-synuclein fibrils in vitro: implications for Lewy body diseases," Neurobiology of Disease, vol. 25, no. 2, pp. 446-454, 2007.

[187] F. Leypoldt, M. Flajolet, and A. Methner, "Neuronal differentiation of cultured human NTERA-2cl.D1 cells leads to increased expression of synapsins," Neuroscience Letters, vol. 324, no. 1, pp. 37-40, 2002.

[188] Z. J. Sahab, M. D. Hall, L. Zhang, A. K. Cheema, and S. W. Byers, "Tumor suppressor RARRES1 regulates DLG2, PP2A, VCP, EB1, and Ankrd26," Journal of Cancer, vol. 1, pp. 14-22, 2010.

[189] G. de Chiara, M. E. Marcocci, L. Civitelli et al., "APP processing induced by herpes simplex virus type 1 (HSV1) yields several APP fragments in human and rat neuronal cells," PLoS ONE, vol. 5, no. 11, 2010.

[190] R. Piacentini, L. Civitelli, C. Ripoli et al., "HSV-1 promotes $\mathrm{Ca}^{2+}$-mediated APP phosphorylation and $\mathrm{A} \beta$ accumulation in rat cortical neurons," Neurobiology of Aging. http://www.ncbi.nlm.nih.gov/pubmed?term=20674092 [uid]. In press.

[191] M. A. Wozniak, R. F. Itzhaki, S. J. Shipley, and C. B. Dobson, "Herpes simplex virus infection causes cellular $\beta$-amyloid accumulation and secretase upregulation," Neuroscience Letters, vol. 429, no. 2-3, pp. 95-100, 2007.

[192] E. Boelen, F. R. Stassen, A. J. van der Ven et al., "Detection of amyloid beta aggregates in the brain of BALB/c mice after Chlamydia pneumoniae infection," Acta Neuropathologica, vol. 114, no. 3, pp. 255-261, 2007.

[193] C. S. Little, C. J. Hammond, A. MacIntyre, B. J. Balin, and D. M. Appelt, "Chlamydia pneumoniae induces Alzheimer-like amyloid plaques in brains of BALB/c mice," Neurobiology of Aging, vol. 25, no. 4, pp. 419-429, 2004.

[194] L. Thirumangalakudi, A. Prakasam, R. Zhang et al., "High cholesterol-induced neuroinflammation and amyloid precursor protein processing correlate with loss of working memory in mice," Journal of Neurochemistry, vol. 106, no. 1, pp. 475-485, 2008.

[195] R. P. J. Prasanthi, E. Schommer, S. Thomasson, A. Thompson, G. Feist, and O. Ghribi, "Regulation of $\beta$-amyloid levels in the brain of cholesterol-fed rabbit, a model system for sporadic Alzheimer's disease," Mechanisms of Ageing and Development, vol. 129, no. 11, pp. 649-655, 2008.

[196] S. Sharma, R. P. J. Prasanthi, E. Schommer, G. Feist, and O. Ghribi, "Hypercholesterolemia-induced $\mathrm{A} \beta$ accumulation in rabbit brain is associated with alteration in IGF-1 signaling," Neurobiology of Disease, vol. 32, no. 3, pp. 426-432, 2008.

[197] C. Ullrich, M. Pirchl, and C. Humpel, "Hypercholesterolemia in rats impairs the cholinergic system and leads to memory deficits," Molecular and Cellular Neuroscience, vol. 45, no. 4, pp. 408-417, 2010.
[198] C. E. Zhang, W. Wei, Y. H. Liu et al., "Hyperhomocysteinemia increases beta-amyloid by enhancing expression of gammasecretase and phosphorylation of amyloid precursor protein in rat brain," The American Journal of Pathology, vol. 174, pp. 1481-1491, 2009.

[199] S. Capsoni, G. Ugolini, A. Comparini, F. Ruberti, N. Berardi, and A. Cattaneo, "Alzheimer-like neurodegeneration in aged antinerve growth factor transgenic mice," Proceedings of the National Academy of Sciences of the United States of America, vol. 97, no. 12, pp. 6826-6831, 2000.

[200] H. Kitaguchi, H. Tomimoto, M. Ihara et al., "Chronic cerebral hypoperfusion accelerates amyloid $\beta$ deposition in APPSwInd transgenic mice," Brain Research, vol. 1294, pp. 202-210, 2009.

[201] L. Li, X. Zhang, D. Yang, G. Luo, S. Chen, and W. Le, "Hypoxia increases Abeta generation by altering beta- and gamma-cleavage of APP," Neurobiology of Aging, vol. 30, pp. 1091-1098, 2009.

[202] C. Zhiyou, Y. Yong, S. Shanquan et al., "Upregulation of BACE1 and $\beta$-amyloid protein mediated by chronic cerebral hypoperfusion contributes to cognitive impairment and pathogenesis of Alzheimer's disease," Neurochemical Research, vol. 34, no. 7, pp. 1226-1235, 2009.

[203] R. Pluta, M. Ułamek, and M. Jabłoński, “Alzheimer’s mechanisms in ischemic brain degeneration," Anatomical Record, vol. 292, no. 12, pp. 1863-1881, 2009.

[204] Z. G. Li, W. Zhang, and A. A. F. Sima, "Alzheimer-like changes in rat models of spontaneous diabetes," Diabetes, vol. 56, no. 7, pp. 1817-1824, 2007.

[205] M. Salkovic-Petrisic, F. Tribl, M. Schmidt, S. Hoyer, and P. Riederer, "Alzheimer-like changes in protein kinase B and glycogen synthase kinase-3 in rat frontal cortex and hippocampus after damage to the insulin signalling pathway," Journal of Neurochemistry, vol. 96, no. 4, pp. 1005-1015, 2006.

[206] H. Q. Yang, Z. K. Sun, Q. H. Jiang, Q. Shang, and J. Xu, "Effect of estrogen-depletion and 17beta-estradiol replacement therapy upon rat hippocampus beta-amyloid generation," Chinese Medical Journal, vol. 89, no. 37, pp. 2658-2661, 2009.

[207] J. P. T. Corcoran, P. L. So, and M. Maden, "Disruption of the retinoid signalling pathway causes a deposition of amyloid $\beta$ in the adult rat brain," European Journal of Neuroscience, vol. 20, no. 4, pp. 896-902, 2004.

[208] L. Letenneur, K. Pérès, H. Fleury et al., "Seropositivity to Herpes Simplex Virus antibodies and risk of Alzheimer's disease: a population-based cohort study," PLoS ONE, vol. 3, no. 11, Article ID e3637, 2008.

[209] W. R. Lin, D. Shang, and R. F. Itzhaki, "Neurotropic viruses and Alzheimer disease: interaction of herpes simplex type I virus and apolipoprotein E in the etiology of the disease," Molecular and Chemical Neuropathology, vol. 28, no. 1-3, pp. 135-141, 1996.

[210] C. J. Hammond, L. R. Hallock, R. J. Howanski, D. M. Appelt, C. S. Little, and B. J. Balin, "Immunohistological detection of Chlamydia pneumoniae in the Alzheimer's disease brain," BMC Neuroscience, vol. 11, article 121, 2010.

[211] K. Shima, G. Kuhlenbäumer, and J. Rupp, "Chlamydia pneumoniae infection and Alzheimer's disease: a connection to remember?" Medical Microbiology and Immunology, vol. 199, no. 4, pp. 283-289, 2010.

[212] J. Kountouras, M. Tsolaki, E. Gavalas et al., "Relationship between Helicobacter pylori infection and Alzheimer disease," Neurology, vol. 66, no. 6, pp. 938-940, 2006. 
[213] M. Malaguarnera, R. Bella, G. Alagona, R. Ferri, A. Carnemolla, and G. Pennisi, "Helicobacter pylori and Alzheimer's disease: a possible link," European Journal of Internal Medicine, vol. 15, no. 6, pp. 381-386, 2004.

[214] M. A. Pappolla, T. K. Bryant-Thomas, D. Herbert et al., "Mild hypercholesterolemia is an early risk factor for the development of Alzheimer amyloid pathology," Neurology, vol. 61, no. 2, pp. 199-205, 2003.

[215] M. M. Mielke, P. P. Zandi, H. Shao et al., "The 32-year relationship between cholesterol and dementia from midlife to late life," Neurology, vol. 75, no. 21, pp. 1888-1895, 2010.

[216] J. C. de la Torre, "The vascular hypothesis of Alzheimer's disease: bench to bedside and beyond," Neurodegenerative Diseases, vol. 7, no. 1-3, pp. 116-121, 2010.

[217] M. van Oijen, F. J. de Jong, J. C. Witteman, A. Hofman, P. J. Koudstaal, and M. M. Breteler, "Atherosclerosis and risk for dementia," Annals of Neurology, vol. 61, pp. 403-410, 2007.

[218] A. E. Roher, C. Esh, T. A. Kokjohn et al., "Circle of willis atherosclerosis is a risk factor for sporadic Alzheimer's disease," Arteriosclerosis, Thrombosis, and Vascular Biology, vol. 23, no. 11, pp. 2055-2062, 2003.

[219] A. E. Roher, C. Esh, A. Rahman, T. A. Kokjohn, and T. G. Beach, "Atherosclerosis of cerebral arteries in Alzheimer disease," Stroke, vol. 35, no. 11, pp. 2623-2627, 2004.

[220] J. W. Miller, "Homocysteine and Alzheimer's disease," Nutrition Reviews, vol. 57, no. 4, pp. 126-129, 1999.

[221] E. M. C. Schrijvers, J. C. M. Witteman, E. J. G. Sijbrands, A. Hofman, P. J. Koudstaal, and M. M. B. Breteler, "Insulin metabolism and the risk of Alzheimer disease: the Rotterdam Study," Neurology, vol. 75, no. 22, pp. 1982-1987, 2010.

[222] C. J. Pike, J. C. Carroll, E. R. Rosario, and A. M. Barron, "Protective actions of sex steroid hormones in Alzheimer's disease," Frontiers in Neuroendocrinology, vol. 30, no. 2, pp. 239-258, 2009.

[223] M. I. Geerlings, L. J. Launer, F. H. de Jong et al., "Endogenous estradiol and risk of dementia in women and men: the Rotterdam study," Annals of Neurology, vol. 53, no. 5, pp. 607-615, 2003.

[224] G. Ravaglia, P. Forti, F. Maioli et al., "Endogenous sex hormones as risk factors for dementia in elderly men and women," Journals of Gerontology Series A, vol. 62, no. 9, pp. 1035-1041, 2007.

[225] F. J. Jimenez-Jimenez, J. A. Molina, F. de Bustos et al., "Serum levels of beta-carotene, alpha-carotene and vitamin A in patients with Alzheimer's disease," European Journal of Neurology, vol. 6, pp. 495-497, 1999.

[226] C. J. Carter, "APP, APOE, complement receptor 1, clusterin and PICALM and their involvement in the herpes simplex life cycle," Neuroscience Letters, vol. 483, no. 2, pp. 96-100, 2010.

[227] L. Jones, P. A. Holmans, M. L. Hamshere et al., "Genetic evidence implicates the immune system and cholesterol metabolism in the aetiology of Alzheimer's disease," PLoS ONE, vol. 5, no. 11, Article ID e13950, 2010.

[228] C. J. Carter, "Convergence of genes implicated in Alzheimer's disease on the cerebral cholesterol shuttle: APP, cholesterol, lipoproteins, and atherosclerosis," Neurochemistry International, vol. 50, no. 1, pp. 12-38, 2007.

[229] A. C. Naj, G. W. Beecham, E. R. Martin et al., "Dementia revealed: novel chromosome 6 locus for Late-onset Alzheimer disease provides genetic evidence for Folatepathway abnormalities," PLoS Genetics, vol. 6, no. 9, 2010.

[230] C. J. Carter, “Alzheimer's disease: a pathogenetic autoimmune disorder caused by herpes simplex in a gene-dependent manner," International Journal of Alzheimer's Disease, vol. 2010, Article ID 140539, 17 pages, 2010.

[231] D. Iacono, W. R. Markesbery, M. Gross et al., "The Nun Study: clinically silent AD, neuronal hypertrophy, and linguistic skills in early life," Neurology, vol. 73, no. 9, pp. 665673, 2009.

[232] D. A. Snowdon, "Healthy aging and dementia: findings from the Nun Study," Annals of Internal Medicine, vol. 139, no. 5, pp. 450-454, 2003.

[233] S. L. Tyas, D. A. Snowdon, M. F. Desrosiers, K. P. Riley, and W. R. Markesbery, "Healthy ageing in the Nun Study: definition and neuropathologic correlates," Age and Ageing, vol. 36, no. 6, pp. 650-655, 2007.

[234] D. S. Wolf, M. Gearing, D. A. Snowdon, H. Mori, W. R. Markesbery, and S. S. Mirra, "Progression of regional neuropathology in Alzheimer disease and normal elderly: findings from the Nun Study," Alzheimer Disease and Associated Disorders, vol. 13, no. 4, pp. 226-231, 1999.

[235] M. Colucci, S. Cammarata, A. Assini et al., "The number of pregnancies is a risk factor for Alzheimer's disease," European Journal of Neurology, vol. 13, no. 12, pp. 1374-1377, 2006.

[236] J. Kountouras, M. Boziki, E. Gavalas et al., "Eradication of Helicobacter pylori may be beneficial in the management of Alzheimer's disease," Journal of Neurology, vol. 256, no. 5, pp. 758-767, 2009.

[237] T. A. Ala, R. C. Doss, and C. J. Sullivan, "Reversible dementia: a case of cryptococcal meningitis masquerading as Alzheimer's disease," Journal of Alzheimer's Disease, vol. 6, no. 5, pp. 503-508, 2004.

[238] M. Hoffmann, J. Muniz, E. Carroll, and J. De Villasante, "Cryptococcal meningitis misdiagnosed as Alzheimer's disease: complete neurological and cognitive recovery with treatment," Journal of Alzheimer's Disease, vol. 16, no. 3, pp. 517-520, 2009.

[239] E. L. Tobinick and H. Gross, "Rapid cognitive improvement in Alzheimer's disease following perispinal etanercept administration," Journal of Neuroinflammation, vol. 5, article 2, 2008.

[240] I. Marie and E. Guglielmino, "Non tuberculous anti-TNF associated opportunistic infections," Revue de Medecine Interne, vol. 31, no. 5, pp. 353-360, 2010.

[241] M. C. Morris, D. A. Evans, J. L. Bienias et al., "Consumption of fish and n-3 fatty acids and risk of incident Alzheimer disease," Archives of Neurology, vol. 60, no. 7, pp. 940-946, 2003.

[242] Y. Gu, J. W. Nieves, Y. Stern, J. A. Luchsinger, and N. Scarmeas, "Food combination and Alzheimer disease risk: a protective diet," Archives of Neurology, vol. 67, no. 6, pp. 699706, 2010.

[243] N. Scarmeas, Y. Stern, R. Mayeux, and J. A. Luchsinger, "Mediterranean diet, Alzheimer disease, and vascular mediation," Archives of Neurology, vol. 63, no. 12, pp. 1709-1717, 2006.

[244] B. Wolozin, W. Kellman, P. Ruosseau, G. G. Celesia, and G. Siegel, "Decreased prevalence of Alzheimer disease associated with 3-hydroxy-3-methyglutaryl coenzyme A reductase inhibitors," Archives of Neurology, vol. 57, no. 10, pp. 1439$1443,2000$.

[245] T. F. Hughes, R. Andel, B. J. Small et al., "Midlife fruit and vegetable consumption and risk of dementia in later life in Swedish twins," American Journal of Geriatric Psychiatry, vol. 18, no. 5, pp. 413-420, 2010.

[246] L. M. Bermejo, A. Aparicio, P. Andrés, A. M. López-Sobaler, and R. M. Ortega, "The influence of fruit and vegetable intake 
on the nutritional status and plasma homocysteine levels of institutionalised elderly people," Public Health Nutrition, vol. 10, no. 3, pp. 266-272, 2007.

[247] J. A. Luchsinger, M. X. Tang, J. Miller, R. Green, and R. Mayeux, "Higher folate intake is related to lower risk of Alzheimer's disease in the elderly," Journal of Nutrition, Health and Aging, vol. 12, no. 9, pp. 648-650, 2008.

[248] P. L. McGeer, M. Schulzer, and E. G. McGeer, "Arthritis and anti-inflammatory agents as possible protective factors for Alzheimer's disease: a review of 17 epidemiologic studies," Neurology, vol. 47, no. 2, pp. 425-432, 1996.

[249] E. H. Corder, A. M. Saunders, W. J. Strittmatter et al., "Gene dose of apolipoprotein E type 4 allele and the risk of Alzheimer's disease in late onset families," Science, vol. 261, no. 5123, pp. 921-923, 1993.

[250] H. C. Gérard, E. Fomicheva, J. A. Whittum-Hudson, and A. P. Hudson, "Apolipoprotein E4 enhances attachment of Chlamydophila (Chlamydia) pneumoniae elementary bodies to host cells," Microbial Pathogenesis, vol. 44, no. 4, pp. 279285, 2008.

[251] E. P. de Chaves and V. Narayanaswami, "Apolipoprotein E and cholesterol in aging and disease in the brain," Future Lipidology, vol. 3, no. 5, pp. 505-530, 2008.

[252] R. Elosua, J. M. Ordovas, L. A. Cupples et al., "Association of APOE genotype with carotid atherosclerosis in men and women: the Framingham Heart Study," Journal of Lipid Research, vol. 45, no. 10, pp. 1868-1875, 2004.

[253] H. Minagawa, J. S. Gong, C. G. Jung et al., "Mechanism underlying apolipoprotein E (ApoE) isoform-dependent lipid efflux from neural cells in culture," Journal of Neuroscience Research, vol. 87, no. 11, pp. 2498-2508, 2009.

[254] H. Xiong, D. Callaghan, A. Jones et al., "Cholesterol retention in Alzheimer's brain is responsible for high beta- and gamma-secretase activities and Abeta production," Neurobiology of Disease, vol. 29, no. 3, pp. 422-437, 2008.

[255] M. S. Weintraub, S. Eisenberg, and J. L. Breslow, "Dietary fat clearance in normal subjects is regulated by genetic variation in apolipoprotein E," Journal of Clinical Investigation, vol. 80, no. 6, pp. 1571-1577, 1987.

[256] J. H. Powers, B. L. Buster, C. J. Reist et al., "Complementindependent binding of microorganisms to primate erythrocytes in vitro by cross-linked monoclonal antibodies via complement receptor 1," Infection and Immunity, vol. 63, no. 4, pp. 1329-1335, 1995.

[257] S. M. Levitz, "Receptor-mediated recognition of Cryptococcus neoformans," Japanese Journal of Medical Mycology, vol. 43, no. 3, pp. 133-136, 2002.

[258] D. Belstrom, P. Holmstrup, C. Damgaard et al., "The atherogenicbacterium Porphyromonas gingivalis evades circulating phagocytes by adhering to erythrocytes," Infection and Immunity, vol. 79, no. 4, pp. 1559-1565, 2011.

[259] A. R. Kamer, R. G. Craig, A. P. Dasanayake, M. Brys, L. Glodzik-Sobanska, and M. J. de Leon, "Inflammation and Alzheimer's disease: possible role of periodontal diseases," Alzheimer's and Dementia, vol. 4, no. 4, pp. 242-250, 2008.

[260] M. Puolakkainen, C. C. Kuo, and L. A. Campbell, "Chlamydia pneumoniae uses the mannose 6-phosphate/insulin-like growth factor 2 receptor for infection of endothelial cells," Infection and Immunity, vol. 73, no. 8, pp. 4620-4625, 2005.

[261] F. Tebar, S. K. Bohlander, and A. Sorkin, "Clathrin assembly lymphoid myeloid leukemia (CALM) protein: localization in endocytic-coated pits, interactions with clathrin, and the impact of overexpression on clathrin-mediated traffic,"
Molecular Biology of the Cell, vol. 10, no. 8, pp. 2687-2702, 1999.

[262] E. S. Stuart, W. C. Webley, and L. C. Norkin, "Lipid rafts, caveolae, caveolin-1, and entry by Chlamydiae into host cells," Experimental Cell Research, vol. 287, no. 1, pp. 67-78, 2003.

[263] C. M. Crump, B. Bruun, S. Bell, L. E. Pomeranz, T. Minson, and H. M. Browne, "Alphaherpesvirus glycoprotein M causes the relocalization of plasma membrane proteins," Journal of General Virology, vol. 85, no. 12, pp. 3517-3527, 2004.

[264] A. Fraile-Ramos, T. A. Kohout, M. Waldhoer, and M. Marsh, "Endocytosis of the viral chemokine receptor US28 does not require beta-arrestins but is dependent on the clathrinmediated pathway," Traffic, vol. 4, no. 4, pp. 243-253, 2003.

[265] H. Parker, K. Chitcholtan, M. B. Hampton, and J. I. Keenan, "Uptake of Helicobacter pylori outer membrane vesicles by gastric epithelial cells," Infection and Immunity, vol. 78, no. 12, pp. 5054-5061, 2010.

[266] M. Hammarstedt, J. Ahlqvist, S. Jacobson, H. Garoff, and A. Fogdell-Hahn, "Purification of infectious human herpesvirus $6 \mathrm{~A}$ virions and association of host cell proteins," Virology Journal, vol. 4, article 101, 2007.

[267] J. Tschopp, A. Chonn, S. Hertig, and L. E. French, “Clusterin, the human apolipoprotein and complement inhibitor, binds to complement C7, C8 $\beta$, and the b domain of C9," Journal of Immunology, vol. 151, no. 4, pp. 2159-2165, 1993.

[268] R. D. Bell, A. P. Sagare, A. E. Friedman et al., "Transport pathways for clearance of human Alzheimer's amyloid betapeptide and apolipoproteins $\mathrm{E}$ and $\mathrm{J}$ in the mouse central nervous system," Journal of Cerebral Blood Flow \& Metabolism, vol. 27, no. 5, pp. 909-918, 2007.

[269] E. Olano-Martin, E. Anil, M. J. Caslake et al., "Contribution of apolipoprotein E genotype and docosahexaenoic acid to the LDL-cholesterol response to fish oil," Atherosclerosis, vol. 209, no. 1, pp. 104-110, 2010.

[270] H. Evrengul, H. Tanriverdi, O. Kuru et al., "Elevated homocysteine levels in patients with slow coronary flow: relationship with Helicobacter pylori infection," Helicobacter, vol. 12, no. 4, pp. 298-305, 2007.

[271] V. Vitvitsky, M. Thomas, A. Ghorpade, H. E. Gendelman, and R. Banerjee, "A functional transsulfuration pathway in the brain links to glutathione homeostasis," Journal of Biological Chemistry, vol. 281, no. 47, pp. 35785-35793, 2006.

[272] A. T. Palamara, C. F. Perno, M. R. Ciriolo et al., "Evidence for antiviral activity of glutathione: in vitro inhibition of herpes simplex virus type 1 replication," Antiviral Research, vol. 27, no. 3, pp. 237-253, 1995.

[273] K. Shibayama, J. Wachino, Y. Arakawa, M. Saidijam, N. G. Rutherford, and P. J. Henderson, "Metabolism of glutamine and glutathione via gamma-glutamyltranspeptidase and glutamate transport in Helicobacter pylori: possible significance in the pathophysiology of the organism," Molecular Microbiology, vol. 64, no. 2, pp. 396-406, 2007.

[274] N. Ballatori, S. M. Krance, S. Notenboom, S. Shi, K. Tieu, and C. L. Hammond, "Glutathione dysregulation and the etiology and progression of human diseases," Biological Chemistry, vol. 390, no. 3, pp. 191-214, 2009.

[275] O. H. Stanger, H. J. Semmelrock, P. Rehak et al., "Hyperhomocyst(e)inemia and Chlamydia pneumoniae IgG seropositivity in patients with coronary artery disease," Atherosclerosis, vol. 162, no. 1, pp. 157-162, 2002.

[276] Y. Sawayama, M. Tatsukawa, S. Maeda, H. Ohnishi, N. Furusyo, and J. Hayashi, "Association of hyperhomocysteinemia and Chlamydia pneumoniae infection with carotid 
atherosclerosis and coronary artery disease in Japanese patients," Journal of Infection and Chemotherapy, vol. 14, no. 3, pp. 232-237, 2008.

[277] M. Mayr, S. Kiechl, J. Willeit, G. Wick, and Q. Xu, "Infections, immunity, and atherosclerosis: associations of antibodies to Chlamydia pneumoniae, Helicobacter pylori, and cytomegalovirus with immune reactions to heat-shock protein 60 and carotid or femoral atherosclerosis," Circulation, vol. 102, no. 8, pp. 833-839, 2000.

[278] J. A. Mohr, H. Long, B. A. McKown, and H. G. Muchmore, "In vitro susceptibility of Cryptococcus neoformans to steroids," Sabouraudia Journal of Medical and Veterinary Mycology, vol. 10, no. 2, pp. 171-172, 1972.

[279] K. Hosoda, H. Shimomura, S. Hayashi, K. Yokota, K. Oguma, and Y. Hirai, "Anabolic utilization of steroid hormones in Helicobacter pylori," FEMS Microbiology Letters, vol. 297, no. 2, pp. 173-179, 2009.

[280] K. Hosoda, H. Shimomura, S. Hayashi, K. Yokota, and Y. Hirai, "Steroid hormones as bactericidal agents to Helicobacter pylori," FEMS Microbiology Letters, vol. 318, no. 1, pp. 68$75,2011$.

[281] C. Clement, P. S. Bhattacharjee, H. E. Kaufman, and J. M. Hill, "Heat-induced reactivation of HSV-1 in latent mice: upregulation in the TG of CD83 and other immune response genes and their LAT-ICP0 locus," Investigative Ophthalmology and Visual Science, vol. 50, no. 6, pp. 2855-2861, 2009.

[282] R. D. Vicetti Miguel, B. S. Sheridan, S. A. K. Harvey, R. S. Schreiner, R. L. Hendricks, and T. L. Cherpes, "17- $\beta$ estradiol promotion of herpes simplex virus type 1 reactivation is estrogen receptor dependent," Journal of Virology, vol. 84, no. 1, pp. 565-572, 2010.

[283] J. D. Kriesel, J. Ricigliano, S. L. Spruance, H. H. Garza Jr., and J. M. Hill, "Neuronal reactivation of herpes simplex virus may involve interleukin-6," Journal of NeuroVirology, vol. 3, no. 6, pp. 441-448, 1997.

[284] S. Noisakran, W. P. Halford, L. Veress, and D. J. J. Carr, "Role of the hypothalamic pituitary adrenal axis and IL-6 in stressinduced reactivation of latent herpes simplex virus type 1 ," Journal of Immunology, vol. 160, no. 11, pp. 5441-5447, 1998.

[285] C. L. Wilcox and E. M. Johnson Jr., "Nerve growth factor deprivation results in the reactivation of latent herpes simplex virus in vitro," Journal of Virology, vol. 61, no. 7, pp. 2311-2315, 1987.

[286] V. Camarena, M. Kobayashi, J. Y. Kim et al., "Nature and duration of growth factor signaling through receptor tyrosine kinases regulates HSV-1 latency in neurons," Cell Host and Microbe, vol. 8, no. 4, pp. 320-330, 2010.

[287] B. Jiang, E. Y. Liao, L. M. Tan, R. C. Dai, Z. J. Xiao, and H. J. Liao, "Effects of long-term replacement therapy of compound nylestriol tablet or low-dose 17 beta-estradiol on the expression of nerve growth factor in OVX rat hippocampal formation," Journal of Central South University, vol. 29, no. 5, pp. 529-533, 2004.

[288] Y. Hashimoto, H. Kawatsura, Y. Shiga, S. Furukawa, and T. Shigeno, "Significance of nerve growth factor content levels after transient forebrain ischemia in gerbils," Neuroscience Letters, vol. 139, no. 1, pp. 45-46, 1992.

[289] M. K. Aghi, T. C. Liu, S. Rabkin, and R. L. Martuza, "Hypoxia enhances the replication of oncolytic herpes simplex virus," Molecular Therapy, vol. 17, no. 1, pp. 51-56, 2009.

[290] Y. X. Sun, L. Minthon, A. Wallmark, S. Warkentin, K. Blennow, and S. Janciauskiene, "Inflammatory markers in matched plasma and cerebrospinal fluid from patients with
Alzheimer's disease," Dementia and Geriatric Cognitive Disorders, vol. 16, no. 3, pp. 136-144, 2003.

[291] J. Kálmán, A. Juhász, G. Laird et al., "Serum interleukin6 levels correlate with the severity of dementia in down syndrome and in Alzheimer's disease," Acta Neurologica Scandinavica, vol. 96, no. 4, pp. 236-240, 1997.

[292] F. Shalit, B. Sredni, L. Stern, E. Kott, and M. Huberman, "Elevated interleukin-6 secretion levels by mononuclear cells of Alzheimer's patients," Neuroscience Letters, vol. 174, no. 2, pp. 130-132, 1994.

[293] P. Kragsbjerg, T. Vikerfors, and H. Holmberg, "Cytokine responses in patients with pneumonia caused by Chlamydia or Mycoplasma," Respiration, vol. 65, no. 4, pp. 299-303, 1998.

[294] N. Mehmet, M. Refik, M. Harputluoglu, Y. Ersoy, N. E. Aydin, and B. Yildirim, "Serum and gastric fluid levels of cytokines and nitrates in gastric diseases infected with Helicobacter pylori," New Microbiologica, vol. 27, no. 2, pp. 139-148, 2004.

[295] D. Delfino, L. Cianci, E. Lupis et al., "Interleukin-6 production by human monocytes stimulated with Cryptococcus neoformans components," Infection and Immunity, vol. 65, no. 6, pp. 2454-2456, 1997.

[296] C. W. Huang, C. C. Lui, W. N. Chang, C. H. Lu, Y. L. Wang, and C. C. Chang, "Elevated basal cortisol level predicts lower hippocampal volume and cognitive decline in Alzheimer's disease," Journal of Clinical Neuroscience, vol. 16, no. 10, pp. 1283-1286, 2009.

[297] K. L. Davis, B. M. Davis, B. S. Greenwald et al., "Cortisol and Alzheimer's disease. I: basal studies," American Journal of Psychiatry, vol. 143, no. 3, pp. 300-305, 1986.

[298] M. A. Wozniak, A. P. Mee, and R. F. Itzhaki, "Herpes simplex virus type 1 DNA is located within Alzheimer's disease amyloid plaques," Journal of Pathology, vol. 217, no. 1, pp. 131-138, 2009.

[299] E. D. Toffanello, E. M. Inelmen, N. Minicuci et al., "Ten-year trends in vitamin intake in free-living healthy elderly people: the risk of subclinical malnutrition," Journal of Nutrition, Health and Aging, vol. 15, no. 2, pp. 99-103, 2011.

[300] R. D. Semba, "The role of vitamin A and related retinoids in immune function," Nutrition Reviews, vol. 56, no. 1, pp. S38S48, 1998.

[301] C. E. Isaacs, R. Kascsak, R. K. Pullarkat, W. Xu, and K. Schneidman, "Inhibition of herpes simplex virus replication by retinoic acid," Antiviral Research, vol. 33, no. 2, pp. 117127, 1997.

[302] C. E. Isaacs, W. Xu, R. K. Pullarkat, and R. Kascsak, "Retinoic acid reduces the yield of herpes simplex virus in Vero cells and alters the N-glycosylation of viral envelope proteins," Antiviral Research, vol. 47, no. 1, pp. 29-40, 2000.

[303] M. Puolakkainen, A. Lee, T. Nosaka, H. Fukushi, C. C. Kuo, and L. A. Campbell, "Retinoic acid inhibits the infectivity and growth of Chlamydia pneumoniae in epithelial and endothelial cells through different receptors," Microbial Pathogenesis, vol. 44, no. 5, pp. 410-416, 2008.

[304] H. Sjunnesson, E. Sturegård, R. Willén, and T. Wadström, "High intake of selenium, $\beta$-carotene, and vitamins A, C, and E reduces growth of Helicobacter pylori in the guinea pig," Comparative Medicine, vol. 51, no. 5, pp. 418-423, 2001.

[305] C. Monari, S. Bevilacqua, M. Piccioni et al., "A microbial polysaccharide reduces the severity of rheumatoid arthritis by influencing Th17 differentiation and proinflammatory cytokines production," Journal of Immunology, vol. 183, no. 1, pp. 191-200, 2009. 
[306] A. Limpach, M. Dalton, R. Miles, and P. Gadson, "Homocysteine inhibits retinoic acid synthesis: a mechanism for homocysteine-induced congenital defects," Experimental Cell Research, vol. 260, no. 1, pp. 166-174, 2000.

[307] K. A. Tanghe, T. A. Garrow, and K. L. Schalinske, "Triiodothyronine treatment attenuates the induction of hepatic glycine $\mathrm{N}$-methyltransferase by retinoic acid and elevates plasma homocysteine concentrations in rats," Journal of Nutrition, vol. 134, no. 11, pp. 2913-2918, 2004.

[308] D. K. Smith, J. M. Greene, S. B. Leonard, T. T. Kuske, D. S. Feldman, and E. B. Feldman, "Vitamin A in hypercholesterolemia," American Journal of the Medical Sciences, vol. 304, no. 1, pp. 20-24, 1992.

[309] S. J. Soscia, J. E. Kirby, K. J. Washicosky et al., "The Alzheimer's disease-associated amyloid beta-protein is an antimicrobial peptide," PLoS ONE, vol. 5, no. 3, Article ID e9505, 2010.

[310] T. Kawamata, I. Tooyama, T. Yamada, D. G. Walker, and P. L. McGeer, "Lactotransferrin immunocytochemistry in Alzheimer and normal human brain," American Journal of Pathology, vol. 142, no. 5, pp. 1574-1585, 1993.

[311] W. J. Lukiw, J. G. Cui, L. Y. Yuan et al., "Acyclovir or Abeta42 peptides attenuate HSV-1-induced miRNA-146a levels in human primary brain cells," Neuroreport, vol. 21, no. 14, pp. 922-927, 2010.

[312] J. H. Sohn, J. O. So, H. J. Hong et al., "Identification of autoantibody against beta-amyloid peptide in the serum of elderly," Frontiers in Bioscience, vol. 14, pp. 3879-3883, 2009.

[313] S. Paul, S. Planque, and Y. Nishiyama, "Immunological origin and functional properties of catalytic autoantibodies to amyloid $\beta$ peptide," Journal of Clinical Immunology, vol. 30, supplement 1, pp. 43-49, 2010.

[314] J. Miklossy, K. Khalili, L. Gern et al., “Borrelia burgdorferi persists in the brain in chronic lyme neuroborreliosis and may be associated with Alzheimer disease," Journal of Alzheimer's Disease, vol. 6, no. 6, pp. 639-649, 2004.

[315] W. R. Lin, M. A. Wozniak, R. J. Cooper, G. K. Wilcock, and R. F. Itzhaki, "Herpesviruses in brain and Alzheimer's disease," Journal of Pathology, vol. 197, pp. 395-402, 2002.

[316] J. Kountouras, M. Boziki, E. Gavalas et al., "Increased cerebrospinal fluid Helicobacter pylori antibody in Alzheimer's disease," International Journal of Neuroscience, vol. 119, no. 6, pp. 765-777, 2009.

[317] J. Choi, S. Y. Lee, K. Kim, and B. K. Choi, "Identification of immunoreactive epitopes of the Porphyromonas gingivalis heat shock protein in periodontitis and atherosclerosis," Journal of Periodontal Research, vol. 46, no. 2, pp. 240-245, 2011.

[318] B. F. Roy, T. Sunderland, D. L. Murphy, and J. M. Morihisa, "Antibody for nerve growth factor detected in patients with Alzheimer's disease," Annals of the New York Academy of Sciences, vol. 540, pp. 398-400, 1988.

[319] P. Foley, H. F. Bradford, M. Docherty et al., "Evidence for the presence of antibodies to cholinergic neurons in the serum of patients with Alzheimer's disease," Journal of Neurology, vol. 235, no. 8, pp. 466-471, 1988.

[320] J. M. Serot, M. C. Bene, B. Gobert, D. Christmann, B. Leheup, and G. C. Faure, "Antibodies to choroid plexus in senile dementia of Alzheimer's disease," Journal of Clinical Pathology, vol. 45, no. 9, pp. 781-783, 1992.

[321] B. S. Kingsley, F. Gaskin, and S. M. Fu, "Human antibodies to neurofibrillary tangles and astrocytes in Alzheimer's disease," Journal of Neuroimmunology, vol. 19, no. 1-2, pp. 89-99, 1988.
[322] D. Kanduc, A. Stufano, G. Lucchese, and A. Kusalik, "Massive peptide sharing between viral and human proteomes," Peptides, vol. 29, no. 10, pp. 1755-1766, 2008.

[323] B. Trost, A. Kusalik, G. Lucchese, and D. Kanduc, "Bacterial peptides are intensively present throughout the human proteome," Self/Nonself, vol. 1, no. 1, pp. 71-74, 2010.

[324] B. Trost, G. Lucchese, A. Stufano, M. Bickis, A. Kusalik, and D. Kanduc, "No human protein is exempt from bacterial motifs, not even one," Self/Nonself, vol. 1, no. 4, pp. 328-334, 2010.

[325] R. Jonsson, B. Nakken, A. K. Halse, K. Skarstein, K. Brokstad, and H. J. Haga, "Heredity and immunology in Sjogren's syndrome," Tidsskr Nor Lageforen, vol. 120, no. 7, pp. 811$814,2000$.

[326] D. Phillips, L. Prentice, M. Upadhyaya et al., "Autosomal dominant inheritance of autoantibodies to thyroid peroxidase and thyroglobulin-studies in families not selected for autoimmune thyroid disease," Journal of Clinical Endocrinology and Metabolism, vol. 72, no. 5, pp. 973-975, 1991.

[327] W. M. Pardridge, "Re-engineering biopharmaceuticals for delivery to brain with molecular Trojan horses," Bioconjugate Chemistry, vol. 19, no. 7, pp. 1327-1338, 2008.

[328] D. L. Mallery, W. A. McEwan, S. R. Bidgood, G. J. Towers, C. M. Johnson, and L. C. James, "Antibodies mediate intracellular immunity through tripartite motif-containing 21 (TRIM21)," in Proceedings of the National Academy of Sciences of the United States of America, vol. 107, no. 46, pp. 19985-19990, November 2010.

[329] D. Vacirca, F. Delunardo, P. Matarrese et al., "Autoantibodies to the adenosine triphosphate synthase play a pathogenetic role in Alzheimer's disease," Neurobiology of Aging. http:// www.ncbi.nlm.nih.gov/pubmed?term=20594618. In press .

[330] W. B. Grant, "Dietary links to Alzheimer's disease: 1999 Update," Journal of Alzheimer's Disease, vol. 1, no. 4-5, pp. 197-201, 1999.

[331] L. B. Lopez, D. Kritz-Silverstein, and E. Barrett-Connor, "High dietary and plasma levels of the omega-3 fatty acid docosahexaenoic acid are associated with decreased dementia risk: the Rancho Bernardo study," Journal of Nutrition, Health and Aging, vol. 15, no. 1, pp. 25-31, 2011.

[332] J. F. Quinn, R. Raman, R. G. Thomas et al., "Docosahexaenoic acid supplementation and cognitive decline in Alzheimer disease: a randomized trial," Journal of the American Medical Association, vol. 304, no. 17, pp. 1903-1911, 2010.

[333] S. A. Frautschy and G. M. Cole, "What was lost in translation in the DHA trial is whom you should intend to treat," Alzheimer's Research \& Therapy, vol. 3, article 2, 2011.

[334] Q. Dai, A. R. Borenstein, Y. Wu, J. C. Jackson, and E. B. Larson, "Fruit and vegetable juices and Alzheimer's disease: the Kame Project," American Journal of Medicine, vol. 119, no. 9, pp. 751-759, 2006. 


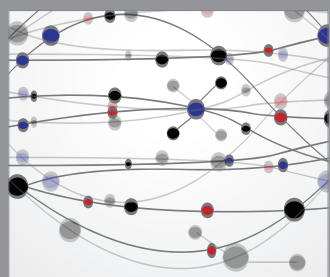

The Scientific World Journal
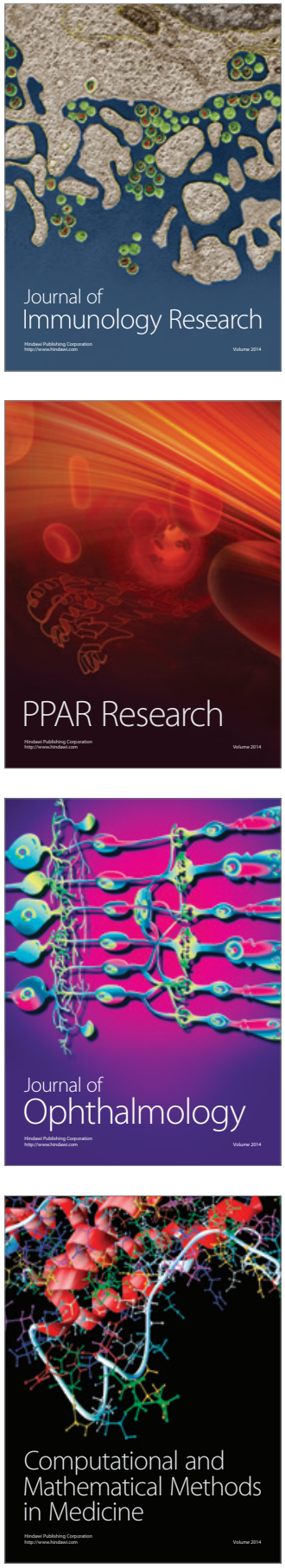

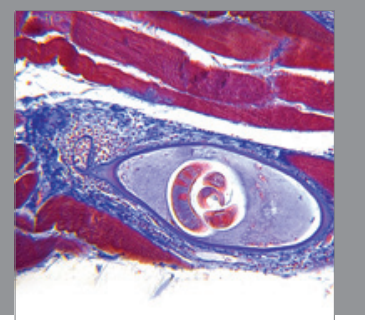

Gastroenterology

Research and Practice
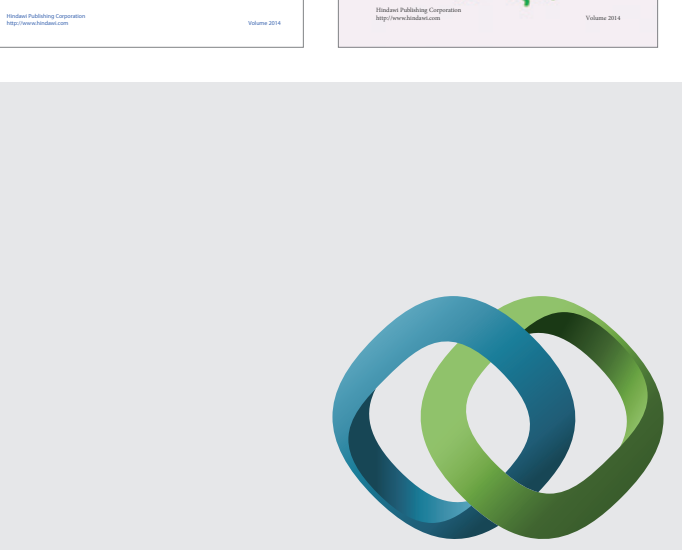

\section{Hindawi}

Submit your manuscripts at

http://www.hindawi.com
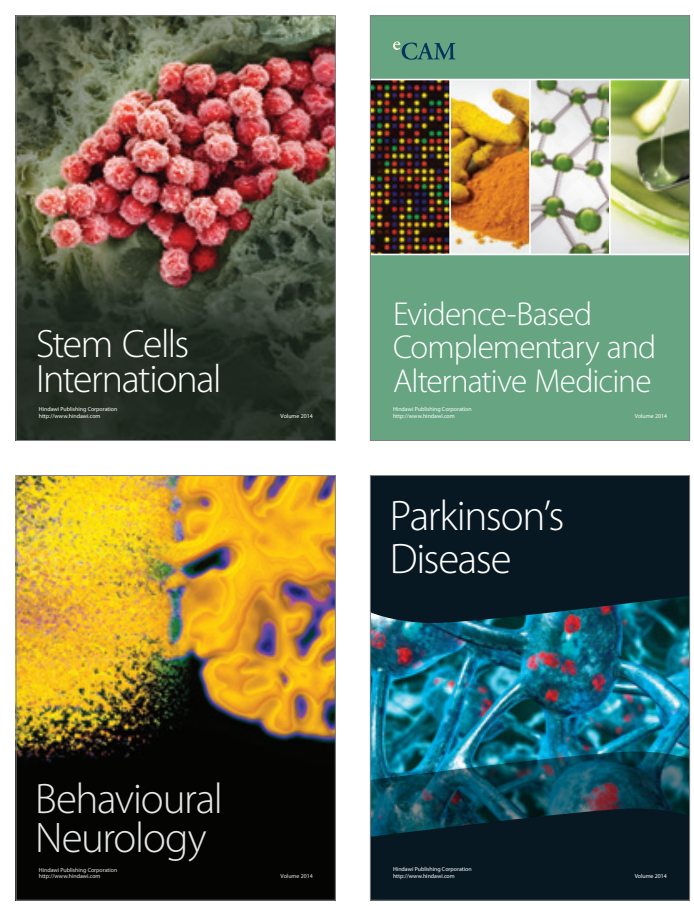

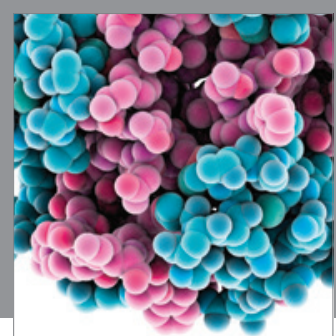

Journal of
Diabetes Research

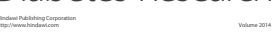

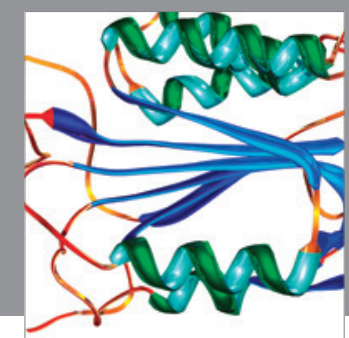

Disease Markers
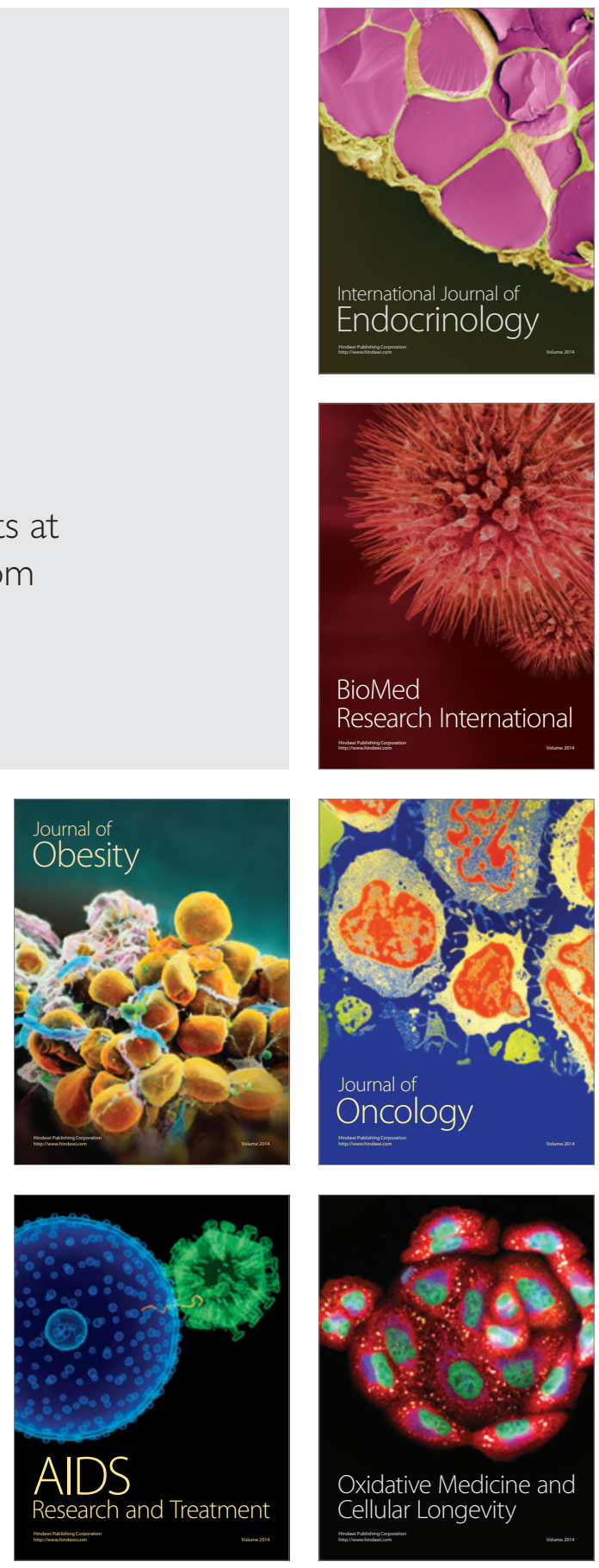